\title{
Neoliberalism, consultants and the privatisation of public policy formulation: The case of Britain's rail industry
}

\begin{abstract}
This paper identifies the importance of private advisers, particularly consultants, in promoting neoliberal prescriptions in public policy formulation in the recent history of British Government. It examines a consultant-dominated attempt to reform British Rail in the 1980s and the fundamental contribution of advisers to the flawed fragmentation and subsequent privatisation of the rail industry. Concepts drawn from Latour's Sociology of Translation are adopted to examine the attempts by Conservative Governments and their private advisory allies to establish networks of support for privatisation. In each of the episodes along the path to privatisation the paper examines attempts to undermine opposition and gain acceptance of the proposed changes with the production of knowledge claims by consultants, that is Latour's process of purification, followed by the consequences for the rail industry. The paper uses critical financial analysis to contrast the knowledge claims made by consultants with the outcomes of rail privatisation, which include extensive, ongoing transfers from taxpayers to private companies. It concludes by highlighting the dangers ensuing from dogmatic and excessive neoliberal public policy formulation.
\end{abstract}

Keywords: Latour; Neoliberalism; consultants; railway privatisation; Railtrack;

Network Rail; Accounting firms; public sector. 


\section{Neoliberalism, consultants and the privatisation of public policy formulation: The case of Britain's rail industry}

\section{Introduction}

One of the striking features of public policy over the past few decades has been the "emphatic turn towards neoliberalism", in countries such as Britain and the USA, and the restructuring of the public sector through the adoption of policies which have emphasised deregulation and privatisation (Harvey, 2007, pp. 2-3). For three decades after 1945 in liberal democratic states there had been a postwar consensus about the role and importance of the public sector, most notably Britain. Britain's Labour Governments of 1945-51 brought within the public sector important industries such as coal, steel, gas and electricity and rail and established the welfare state. In the face of market failures arising from inadequate investment by, for example, private rail companies, public enterprise was promoted as the way to develop an efficient industry which would benefit British capital and society.

The post-war consensus over the state's responsibility for providing core public services came under sustained attack from neoliberals in the 1970s as economies experienced rapid inflation simultaneously with faltering or negative economic growth, a phenomenon referred to as stagflation. Two important political beneficiaries of these economic changes were Margaret Thatcher in Britain and Ronald Reagan in the US, both of whom subscribed to the neoliberal New Right Agenda and highlighted the need to reduce state provision of services and state ownership in order to promote private ownership and encourage entrepreneurial freedom. Government was identified as "the problem" not "the solution" (Reagan, 1981; cited by McSweeney (2009, p.839)). 
Margaret Thatcher concurred, but took a more overtly ideological approach than Ronald Reagan, even declaring Messianically that while "economics are the method", the "object is to change the soul" (Harvey, 2007, p. 23). Although their rhetoric varied, both leaders "took what had hitherto been minority political, ideological, and intellectual positions and made them mainstream" (Harvey, 2007, p. 62).

In Britain, the Conservative Governments of the 1980s led by Margaret Thatcher gradually developed a wide-ranging privatisation programme. Nationalised monopoly utilities such as gas, water and electricity were sold into private ownership through share flotations. Various motives lay behind the privatisation policy. Early debate was dominated by economic arguments about promoting efficiency through private ownership and market disciplines (Flemming \& Mayer, 1997; Goodman \& Loveman, 1991; Letza et al., 2004; Ogden, 1997; Shaoul, 1997). Later arguments focused on privatisation's role in reducing the role of government and raising revenue to reduce public sector borrowing (Letza et al., 2004; Ogden, 1997; Shaoul, 1997). Economic models and efficiency arguments were used to legitimise privatisations but, according to Shaoul (1997, p. 479), the ultimate result in each case was to benefit capitalism by "transferring wealth from the public at large to a relatively few individuals and corporate entities" in the private sector. Public policy in Britain and other advanced capitalist countries became dominated by the neoliberal agenda that has sought to fully privatise state owned enterprises, or to transfer activities to the private sector through various public-private partnerships (Edwards and Shaoul, 2003, p. 397). Following privatisation and public management reforms, a "third wave" of neoliberalisation reforms arose where members of central governments and 
public servants "increasingly think and behave like entrepreneurs" (Morales et al., 2014, p. 426).

This paper focuses on rail privatisation which has three unique features: it was the most complex privatisation undertaken by the Conservatives; it was followed by a continuing wealth transfer to the private sector through increased subsidy and, as a senior manager in the industry argued, it was unique in "that the nature of the new structure was not decided by the experts working within the industry but by people from outside such as consultants ..." (Green, cited in Wolmar, 2005, p. 58). Informed by concepts drawn from Latour's Sociology of Translation (Actor-Network Theory), the paper focuses on the knowledge claims provided by consultants and advisers in the formulation of public policy related to the reform and privatisation of Britain's rail industry. This paper responds to the need, highlighted by Christensen and Skaerbaek (2010, p. 543), for "further longitudinal study of cases" where consultancy outputs, often co-produced with the client, are influential in delivering controversial accounting changes in public sector organisations. It also answers Cooper and Robson's (2006, p. 434) call for studies of how 'the translation of multiple issues to 'accounting issues' now gives enormous influence to accounting firms in ... economic and political life". Hence, the analysis focuses on a consultant-dominated attempt to reform Britain's nationalised rail industry in the 1980s, and the subsequent fundamental contribution of consultants to the fragmentation and privatisation of the rail industry in the 1990s. The analysis is longitudinal, examining the two key phases of public policy towards Britain's rail industry, and highlights the crucial influence of consultants in formulating and implementing public policy. 
Consultants and advisers, drawn predominantly from the large accountancy firms, became key figures in the "neo-liberal alliance" that implemented privatisation (Martin, 1993, p. 6) through the transformation of contested values and claims. The advisory role of consultants, particularly accountants, was not simply "technical", for privatisation advice most importantly "becomes intertwined with economic and public policy decisions" (Arnold and Cooper, 1999, p. 133). Privatisation consultants play a strategic policy role advising, for example, on the need for neoliberal reforms to create an "enabling environment" for privatisation, and the necessity for pre-privatisation restructuring (Arnold and Cooper, 1999, p. 133). Economic and political factors were both important in the increasingly influential role gained by consultants. In the 1980s, there was a major change in the nature of accountancy work. Once the market for traditional audit services became full to capacity firms provided new services to increase revenue, the bulk of which came from providing consulting services (Suddaby et al., 2007, p. 340). In Britain, auditing fees now comprise under $40 \%$ of the revenue of the large accounting firms, compared to $70 \%$ in 1980 (Smith, 2012, p. 9).

Political factors were also important in creating a market for private sector advisory services (Arnold and Cooper, 1999, p. 135). Governments regarded private consultants as more likely to be sympathetic to the goal of privatisation than civil servants, thereby allowing governments to avoid the possibility that privatisation programmes might be undermined by opposition within state bureaucracies (Arnold and Cooper, 1999, p. 135). Further, the State was keen to use accounting's professional status to bring "an appearance of legitimacy and technical correctness" to privatisation, in order 
to reassure a public "concerned about the corruptive influences of market capitalism" (Arnold and Cooper, 1999, p. 134).

Although governments in Britain have increasingly resorted to using consultants there have been several highly critical reports on this process. Two National Audit Office (NAO) reports $(2001,2006)$ criticised the amounts spent on consultants, which averaged over $£ 1$ billion per year, and cast doubt on the extent to which value for money is obtained.. (see Appendix A for a list of all abbreviations used). The Select Committee on Public Accounts later concurred, arguing that government departments have a "poor understanding of what value they obtain" from consultants; they also criticised the dependency of some departments on consultants as "unacceptable" (Public Accounts Committee, 2010, paras. 1, 2, p. 5). The Transport Department, in particular, was criticised for spending $£ 70$ on consultants for every $£ 100$ spent on its own staff (Public Accounts Committee, 2010, para. 2, p. 5).

The use of consultants in the public sector has also been the subject of a range of critical academic papers. One critical study argued that consultants presented "phantom images" of idealised public sector accounting, based on the adoption of accrual accounting, and so "became an essential ingredient in public sector accounting change" (Christensen, 2005, pp. 447-448). Another paper examined the work of consultants in Britain's National Health Service, arguing that they were "intellectual mercenaries", providing market-orientated views which appear to have been employed "to provide legitimation" for a drive to "downsize" acute care (Leys, 1999, p. 447). An analysis of a consultancy based project to introduce a financial management initiative into the Probation Service provided "a vivid illustration of the difficulty of applying the 
traditional management accounting principles" in the public sector (Humphrey, 1994, p. 171). A more positive view of consultants working in the public sector, using interview evidence, was provided by Lapsley and Oldfield (2001, pp. 540-541) who acquitted them of being "witchdoctors" and found they possessed relevant skills used to deliver some changes in the public sector. An historical study of the development of management consultancy across three countries found that Britain, and to a lesser extent Canada, has been more likely than France to give rise to a "consultocracy" as public sector reforms were implemented, because in the first two countries "management consultancy emerged earlier and is more strongly developed than in France" (Saint-Martin, 1998, p. 322).

This study contributes to the literature on consultants by providing a comprehensive critique of their role in influencing policy concerning Britain's rail industry, highlighting the dominance of neoliberal ideology. The key research question is how consultants were able to exercise influence on public policy formulation to the extent that their knowledge claims, drawn from neoliberal ideology, formed the basis for the 1992 rail privatisation White Paper New opportunities for the railways (Department of Transport, 1992) and the subsequent fragmentation and then privatisation of the rail network.

The next section of the paper explains the paper's methodology and the key theoretical concepts, most especially Latour's ideas of translation and purification, which inform the paper. The third section examines the rise of neoliberal ideology, which framed the rhetoric of knowledge claims in the debates on rail. The fourth section analyses the establishment and role of the Serpell Committee, highlighting the influence of consultants on its attempt to purify British Rail's finances in the 1980s. This is 
followed by an examination of the purification attempts by which consultants provided knowledge claims, based on neoliberal ideology, to support the contested fragmentation model of rail privatisation which was introduced in the 1992 White Paper. Purification is where processes are adopted "that progress ideas toward acceptance" (Christensen and Skaerbaek, 2010, pp. 525). It operates by transforming opinions or statements into what are meant to appear to be hard facts which can provide an effective rhetorical strategy (Berglund and Werr, 2000, p. 652). The four key knowledge claims provided by consultants for the privatisation of British Rail are then contrasted in the sixth section with the outcomes of rail privatisation by analysing the impact of privatisation on infrastructure investment, costs and government subsidy, safety and quality of service. The final section provides a discussion and conclusions on the implications of the contested privatisation for public policy formulation.

\section{Methodology and Theoretical Insights}

The key primary sources for this study of the proposed reform of British Rail and then later its fragmentation and full privatisation were files in The National Archive (TNA) at Kew, London. Documents contained in the files were of three main types.

Firstly, there were those which were communications between British Rail, consultants and politicians which provide details of discussions and decisions related to the Serpell Committee on Railway Finances (1983), which was established to examine critically and make recommendations on British Rail's costs and whose work is analysed in section 4.2. The documents include the process by which consultants were appointed and the impact of their work on the Serpell Committee Report (1983). Most important for the purposes 
of this study were the papers provided by the consultants which examined the then current position of British Rail, with the focus on operational features which impacted on costs and financial performance. In order to analyse the influence of consultants on the proposed radical reform of British Rail which was recommended by the Serpell Committee, all of the 41 files of working papers supporting the Committee's Report were examined. The working papers were grouped into five main categories: British Rail's evidence; Conservative Government evidence; British Rail supporters' evidence, including rail unions and pressure groups; consultants' reports and background papers, including correspondence. Examination of the working papers enabled the influence of the consultants on the final Report to be identified. Given the close relationship between members of the Serpell Committee and the consulting firms contracted by the government, references to the potential for conflicts of interest were a priority in the examination of the documents.

For the privatisation of British Rail, the TNA's website was examined to identify the third type of important file; files held on rail privatisation, which numbered over 1,200. Although some of these files are still withheld under the 30-year confidentiality rule for government papers it was possible to access sufficient files which have been released early to obtain three major consultancy reports prepared for the Conservative Governments responsible for rail privatisation. Additionally, files provided information on other consultancy work undertaken for the government, a major consultancy report prepared for British Rail, and British Rail's unsuccessful attempts to lobby ministers against the fragmented model advocated by the privatisation networks which would see the various components of the British railway network separated and sold to potentially 
many firms. The files were used to capture how the consultants created a discourse which supported the chosen fragmented privatisation model, and the extent to which their neoliberal arguments provided the foundations for the 1992 privatisation White Paper.

The paper also draws on other primary sources, including reports from think tanks, parliamentary debates, parliamentary Select Committee reports, and company accounts. Think tank reports were important in contributing to the development of the fragmented privatisation model. Parliamentary debates on the Serpell Committee highlighted opposition both to its recommendations on British Rail's finances and to the conflict of interest arising from the employment of consultancy firms which seconded Serpell Committee members. Transport Select Committee reports also were critical of both Serpell and the later privatisation proposals. Rail company accounts were important sources for understanding the impact of privatisation on costs and debt.

Examination and interpretation of the evidence which exposes the way in which beliefs and knowledge about the desirability of the radical reform of British Rail and subsequently its privatisation were created and gained acceptance aligns closely with Latour's framework for studying modernity. This paper uses concepts derived from Actor-Network Theory in a flexible way, an approach encouraged by Latour himself who argued that the potentialities of Actor-Network Theory were still "largely untapped, especially the political implications" and so researchers should "continue all the way in developing" its potential (Latour, 1999, pp. 21, 24). Latourian research in its purest form is often criticised for neglecting issues such as political power, economic structures and the social order (Chua, 1995, pp. 116-117). This paper adopts a critical perspective, within Latour's framework, to examine the promotion of neoliberal ideas by consultants 
in the reform and subsequent fragmentation and privatisation of Britain's rail network. It adopts one of the epistemic scripts of knowledge production, bricolage, where the researcher "rather than inventing a new theory or new paradigm, repairs or remodels existing theories by combining various theoretical concepts, ideas and observations" (Boxenbaum and Rouleau, 2011, p. 281). Different knowledge elements are assembled based on factors such as "practical value, and their potential for generating novel insights" (Boxenbaum and Rouleau, 2011, p. 281). This paper generates "novel insights" by combining the Latourian framework, neoliberalism, and empirical work on consultancy reports.

The Latourian (1987) framework has been used previously in a number of studies to analyse changes in accounting practices (see, for example, Chua, 1995; Jupe, 2000; Robson, 1991; Young, 1995). Christensen and Skaerbaek developed this framework to demonstrate how consultancy outputs are used "to settle controversies .... and how they can be successful to stabilize accounting technologies" (2010, p. 524). There is an appealing analogy between science and consultancy "because consultants claim both expertise and independence", and powerful consultancy tools such as statistical methods can be persuasive in influencing organisations (Christensen and Skaerbaek, 2010, p. 527). Thus, the role of consultants often extends beyond that of the technical adviser and "proceeds into processes of persuasion" (Christensen and Skaerbaek, 2010, p. 526) which can be analysed in a Latourian framework.

Latour distinguishes between two sets of practices integral to the structure of knowledge - translation and purification - which in theory must remain "distinct if they are to remain effective" (Latour, 1993, p. 10). Much of the academic work drawing on 
Actor-Network Theory focuses on translation. The focus of translation is on how ideas become accepted or rejected by audiences (Latour, 1987; Gendron and Baker, 2005, p. 533). An idea gains in acceptance when it is "perceived as relevant and natural in solving certain problems" which people face (Gendron and Baker, 2005, p. 533). With translation, there is an "ongoing process by which claims are transformed as proponents seek to enrol other actors" in support (Gendron et al., 2007, p. 105). Chains of translation are constructed as claims are "progressively transformed into facts through the enrolment of people who come to interpret claims and ideas in a way which caters to their own interests" (Gendron and Baker, 2005, p. 533). Ideas are not immutable during the translation process, as an idea "undergoes a number of transformations as actors in the importing field develop interest and take it up" (Gendron and Baker, 2005, p. 563). Translation has been shown to provide many features that are relevant to the analysis of accounting changes and the role of consultants, particularly those from accounting firms (Briers and Chua, 2001; Christensen and Skaerbaek, 2010; Preston et al., 1992). It can be argued that "accounting and scientific practices are clothed in the discourse of neutral, technical, professional endeavour" (Robson, 1991, p. 50). In practice, however, scientific and accounting discourses both involve controversies incorporating much "rhetoric", the "name of the discipline that has, for millennia, studied how people are made to believe and behave and taught people how to persuade others" (Latour, 1987, p. 30). Rhetoric is central to these processes, where there may be a "trial of strength" and so it is necessary for allies to be "shaped and enrolled" if a viewpoint is to prevail (Latour, 1987, pp. 78, 90). 
Latour emphasised the importance of rhetoric in influencing the outcome of scientific debates, where proponents of a new scientific theory need to employ rhetoric in a trial of strength in order to mobilise a large enough network of allies if the theory is to become accepted (Latour, 1987, p. 61). When trials of strength are perceived as successful 'audiences' interests with regard to the idea increase, thereby strengthening the network of support" (Gendron and Baker, 2005, p. 533). A network refers to the webs of support provided by people and resources for particular knowledge claims (Latour, 1987, pp. 180-182). Knowledge claims "are understood to be widely accepted ... when they are supported by stable and solid networks" (Gendron et al., 2007, p. 105). A remarkable development of recent decades has been the growth in, and acceptance of, rhetoric in the form of knowledge claims "emerging in particular from auditors and management consultants" (Christensen and Skaerbaek, 2010, p. 524). It is argued that consultants can be seen as "experts", working in organisations to develop knowledge claims in order to make accounting innovations successful through fact-building (Briers and Chua, 2001; Christensen and Skaerbaek, 2010; Preston et al., 1992). While Latour and Woolgar (1986) and Latour (1987) highlighted the importance of laboratories in the construction of scientific facts, "laboratories can encompass not just the activities of science, but also the production and legitimization of knowledge" by accountants (Gendron et al., 2007, pp. 105-106).

The other practice identified by Latour as integral to the structure of knowledge, purification, is "a useful work requiring instruments, institutions and know-how" (Latour, 1993, p. 78) which progresses ideas towards their acceptance. Purification depends on controversy. Researchers in laboratories, like politicians, "have learned to construct 
controversies and to referee them through convincing experiments" (Latour, 2004, p. 144). Fact making by laboratories is crucial to purification, which results in a fact which "is collectively stabilised from the midst of controversies" but not necessarily accepted by all (Latour, 1987, p. 42). Consultants are frequently enrolled in conditions involving controversy, since such conditions form a pre-condition from which purification may result. Purification can be regarded as a form of mediation (Latour, 1993, p. 78). Fact making relies on mediators which "transform, translate, distort, and modify the meaning or the elements they are supposed to carry" (Latour, 2005, p. 39). Consultancy reports may be regarded, like scientific publications, as "mediators" which rely on scientific method "to achieve their effect" (Christensen and Skaerbaek, 2010, p. 527). Reports drawing on scientific method "do not merely record a reality independent of themselves; they contribute powerfully to shaping, simply by measuring it, the reality they measure" (Callon, 1998, p, 23).

In order to achieve their desired impact on reality, consultants need to transform the "contested values" of neoliberalism into what are argued to be hard facts (Christensen and Skaerbaek, 2010, p. 532). Consultants have performed an important role in many organisations in the "purification" of viewpoints, thus ensuring "accounting innovations become operable" (Christensen and Skaerbaek, 2010, p. 525). While Latour believes that purification and translation should remain separate (Latour, 1993, p. 10), in practice a blending of translation and purification "is important in order to make translations successful" (Christensen and Skaerbaek, 2010, p. 527). This has been clearly demonstrated in many countries which have sought to transform public sector practices, 
values and beliefs according to neoliberal ideology, most notoriously in Great Britain with Prime Minister Thatcher.

The concepts of translation and purification are employed to inform the empirical analysis in sections four and five of this paper. Section four analyses how the Serpel Committee, established to radically reform and so purify British Rail's structure and finances, was heavily influenced in its work and recommendations by the consultants seconded to it. Although Serpell was nominally independent, the Thatcher Government enrolled allies from consultancy firms as Committee members in order to influence the purification process. This purification attempt was followed by the Major Government's fragmentation and privatisation of the rail network, which is examined in section five. Rail privatisation relied heavily on the work of allies from consultancy firms, whose reports were used to transform contested knowledge claims into accepted facts. Privatisation moved towards acceptance in a purification process where consultancy reports acted as mediators. This process was accelerated by the rise of neoliberal ideology. Neoliberalism framed the rhetoric of the controversial knowledge claims provided by the consultants in the debates on rail privatisation.

\section{Neoliberal ideology and its champions}

Under liberal theory, individuals are seen as the engine of wealth creation and of national prosperity, thereby providing the only sure means of promoting the common good. Economic freedom, and hence a free market, encourages independence and individual responsibility, the very antithesis of the dependency and avoidance of personal responsibility that state intervention is said to produce. At the heart of the classical liberal theory developed by Thomas Hobbes and John Locke was the dependent relationship 
between an individual's liberty, the roles assumed by the state and the financial burdens that these would create and, hence, the impact on the sanctity of private property whereby each individual was to be allowed to employ their labour and capital as they believed best. Liberalism saw a need for the state but mainly to ensure the circumstances which would allow individuals the political and economic freedom to pursue their own best interests which was also the source of the well-being of the social collective (see Funnell et al., 2009, ch. 1). This would require that individuals were not burdened with overbearing, inhibiting financial requirements of the state exacted by taxation and other pecuniary imposts, that the state would make economy in service delivery its priority. To liberals, "the market was for the state a principle of limitation, that is the unique place where policymakers had to respect and impose the logic of "laissez-faire" (GuéninParacini and Gendron, 2014, p. 320). Under classical liberalism competition within the private sector was said to provide a surer guarantee of effective resource use than the state, and competition was seen as a "natural phenomenon" (Guénin-Paracini and Gendron, 2014, p. 320).

In contrast to classic liberalism, neoliberalism has been perceived as "radically different", in that "it gives the state an active role in building a society of entrepreneurs competing for resources" (Morales et al., 2014, p. 426). Competition is not regarded as a "primitive datum", rather "it is a formal structure that needs to be developed and constructed" (Guénin-Paracini and Gendron, 2014, p. 320). Hence, neoliberals support "a strong state as both producer and guarantor of a stable market society" (Mirowski, 2013, p. 54). Rather than eliminating the state, neoliberals seek to restructure the state through the rationalisation and marketization of the public sector (Mirowski, 2013, p. 57). Hence, 
in many countries the public sector was opened up to private enterprise through rationalisation in the form of New Public Management (NPM). The foundation of NPM lay in reducing or removing where possible differences between the public and private sectors, a process in which accounting was a key element "since it reflected high trust in the market and private business methods" (Hood, 1995, p. 94). Neoliberalism proposes that "human well-being can best be advanced by liberating individual entrepreneurial freedoms and skills within an institutional framework characterized by strong private property rights, free markets and free trade" (Harvey, 2007, p. 2). Neoliberalism, driven by influential theorists such as Hayek and Friedman, set out to give preference to the sovereignty of the individual (Chabrak, 2011, pp. 460-463), but it also accorded the state a significant role in preserving an institutional framework. The state has to guarantee the integrity of the currency, establish defence, police, and legal structures "to secure private property rights", and guarantee "functioning of markets" (Harvey, 2007, p. 2).

In countries such as Britain, a new public management coalition emerged in the 1980s, drawn from "accounting firms, financial intermediaries, management consultants and business schools" (Hood, 1995, p. 102). This coalition was very influential, with management consultants playing a key role in "packaging, selling and implementing" reforms encompassed by the NPM umbrella (Greer, 1994, p. 29). Alongside full privatisation, NPM reforms included the outsourcing of public services, and schemes such as the Private Finance Initiative and Public Private Partnerships (Shaoul, 2005, p. 468). In Britain in particular, and in many other countries, privatisation and its variants "transformed the public sector and public life in general", and the neoliberal mantra became "private sector good, public sector bad" (Letza et al. 2004, p. 160). This 
neoliberal mantra was used not only to justify rail privatisation itself, but also to validate the privatisation of policy formulation to consultants and think tanks. This went through two phases with Britain's rail industry. The first phase which was started in 1982 by the Thatcher Government was a critical examination by private sector consultants of the operations and financial management of British Rail to provide the means to justify a greater role for the private sector in delivering British Rail's services, here referred to as the attempted purification of British Rail's finances. The second phase, delayed until the Major Government in the 1990s, again enlisted the contributions of private sector consultants to bring about the acceptance of full privatisation of British Rail with the purification of the very controversial policy of rail privatisation. In both the first and second phases, consultants drew heavily on neoliberal ideology to justify their controversial recommendations for the reform and, ultimately, the privatisation of British Rail.

\section{Phase I: Purification of British Rail's finances}

\subsection{Historical background}

In 1945 the Labour Government, led by Prime Minister Attlee, was elected on a manifesto which included a key commitment to bring the principal utilities into public ownership. Although regarded as socialist dogma by some critics, the nationalisation of the coal, gas, electricity and transport industries was partly the logical extension of the previous regulation of essential industries in both world wars, and was intended to benefit business as the output of these industries "would be more widely and cheaply available" (Chick, 1987, p. 106). The nationalisation of Britain's four major rail companies in 1948, along with freight, buses and London Transport, was further justified on several grounds, 
including the record of inadequate investment by private transport companies and the fact that the transport industries contained "strong elements of natural monopolies and externalities" (Millward, 1997, p. 230). The rail companies were run-down and debtridden and had struggled financially in the 20th century because of the decline of traditional industries and the rise of road transport (Wolmar, 2005, p. 21). The integrated rail industry under public ownership was intended to operate more efficiently for the benefit of its users, particularly industry, without being constrained by its former reliance on private capital. In practice, however, British Rail still faced the problem that while over half the costs of operating a railway are associated with infrastructure provision, the service is not "comprehensive and universal" and unavoidable (Shaoul, 2004, p. 30). Thus, rail is quite unlike essential, utilities such as water and gas, which can spread fixed costs over a large number of users.

The problem of full cost recovery meant that throughout Europe rail services required government support (Jupe and Crompton, 2006, p. 1038). In Britain, this came partly in the form of subsidies to cover the operating costs of loss-making passenger services and capital grants which, in theory, were available to facilitate investment. In practice, successive governments compelled British Rail to finance its capital investment with interest-bearing public debt, thus making it virtually impossible to break even (Wolmar, 2005, p. 40). Rail's financial problems under public ownership were exacerbated by the generous terms granted to former shareholders, whose equity was converted into 30-year loan stock with returns in the form of fixed interest payments which British Rail was obliged to pay, even if making losses. Further, there were other financial constraints, such as making British Rail pay for the enforced purchase of over 
500,000 freight wagons owned by customers of the railway companies; many wagons were in such a poor state that they were scrapped immediately (Wolmar, 2005, p. 27).

By the 1970s, British Rail had made progress in improving safety (Wolmar, 2005, p. 100), while making advances in inter-city passenger service provision and delivering some, albeit modest, productivity improvements (Gourvish, 2002, pp. 54, 66). Its market share had been falling steadily for two decades, however, and it became known for its losses. The Conservative Government elected in 1979 was led by Prime Minister Margaret Thatcher who had "a distinct antipathy towards the public sector in general and the railways in particular" (Gourvish, 2002, p. 100). Despite its unprofitability, British Rail was not an early priority for full privatisation given its subsidy dependence and the presumed unpopularity of a major contraction in services. British Rail along with other public sector bodies, however, was subject to rigorous financial discipline by a government "intolerant of (what it saw as) managerial incompetence" (Dent, 1991, p. 724). Thus, British Rail's subsidy and borrowing requirements were strictly controlled and it was required to sell peripheral businesses such as hotels and ferries. Concerned about British Rail's losses in the recession of the early 1980s, the Thatcher Government established the Serpell Committee on Railway Finances, chaired by a former Permanent Secretary of the Transport Department, to review British Rail's performance and to secure improved financial results. The Serpell Committee, which has had very little scrutiny in the academic literature, both prefigured and influenced future events. The Conservative Government enrolled consultants to provide critical reports to the Committee in conditions involving controversy; the Committee's recommendations later influenced the rail privatisation plans in the 1990s. 


\subsection{Consultants and the purification attempts}

Determined to impose rigorous financial discipline on British Rail, the Thatcher Government enrolled allies from the private sector as mediators in a purification process, and heavily influenced the four-person membership of the Serpell Committee which sought British Rail's partial privatisation. This was despite the fact that Transport Secretary David Howell, when establishing the Committee, announced that its Chair Sir David Serpell would have "the necessary position of total independence" (Department of Transport, 1983a). The members included Leslie Bond, a director of the Rank organisation, Jim Butler, from the accountancy firm Peat, Marwick, Mitchell (PMM) (which, in a later merger, became KPMG), and Alfred Goldstein from the consulting engineers R.Travers, Morgan (TM). Both Butler and Goldstein were senior partners in their respective firms. Goldstein's appointment was particularly controversial as he was a close friend of Sir Alan Walters, the Prime Minister's economic adviser, and an "intellectual right-winger fond of theoretical excursions and in favour of converting railways into roads" (Gourvish, 2002, p. 169). The conditions for enrolling consultants "necessarily involve controversy since that forms a pre-condition from which purification may ... eventuate" (Christensen and Skaerbaek, 2010, p. 529). The Committee's membership alone guaranteed controversy irrespective of its aims; controversy which was compounded by the Committee's working practices which involved a significant conflict of interest. Although it examined reports from British Rail and other bodies, a large amount of work was outsourced by the Committee at a cost of $£ 627,000$ (Gourvish, 2002, p. 180) to the two consultancy firms which had seconded senior partners to the Serpell Committee. 
The importance of this outsourcing to consultants by the Committee is shown throughout the Serpell Report. The terms of reference for the consultants reveal their fundamental role in shaping the deliberations of the Committee. TM were commissioned to "examine critically ... the BR Board's present, planned and foreseeable expenditure on engineering" (Serpell, 1983, Annex B), while PMM were commissioned to obtain "financial information .... in particular: to examine and report on British Rail's costs and revenue forecasts .... to assist in the preparation of financial estimates of the likely effects of options for alternative policies identified by the Committee" (Serpell, 1983, Annex C). The covering letter to the Transport Secretary, at the beginning of the Report, makes it clear that chapter 6 , on engineering costs, is based on "advice received" from TM (Serpell, 1983, p. 1). The introduction to the Report asserted that it is a "summation of our own views as an independent Committee" (emphasis added), but explicitly acknowledged that "we have been greatly helped in reaching them by the professional advice of two firms of consultants" who were commissioned to "develop and evaluate" the "network options in Part II" of the Report and to study British Rail's 1982 Budget and Rail Plan (Serpell, 1983, para. 6). These extensive, influential contributions of the consultants were contained in 12 of the 41 files of working papers supporting the Serpell Report. The consultants, although appointed by government, were keen to be seen to assert their independence. When British Rail raised concerns over the role of PMM, for example, it received such a robust response from the firm that British Rail's Director of Finance and Planning felt obliged to reply: "I fully understand and accept your point about the independence of your role in advising the Serpell Committee" (Department of Transport, 1983b). 
Part I of the Serpell Report, which examined British Rail's finances, drew heavily on the 200-page PMM analysis of British Rail and its supporting papers prepared by Committee member Jim Butler, apparently oblivious to the blatant conflict of interest that this represented. Butler had been a partner of PMM since 1965 and Government Director of the Mersey Docks and Harbour Company since 1971. Butler's study emphasised the need for: the reappraisal of engineering standards in order to enable "cost reductions while complying with safety standards"; the reduction in employment costs; the reduction in rolling stock costs by buying in vehicles rather than using the wholly owned subsidiary British Rail Engineering Limited; the reduction of track maintenance and renewal costs; and the reduction of track mileage (Department of Transport, 1983c, paras. 2.7.2, 2.10.1, 2.10.5, 2.10.6, 2.10.7). Part II of the Report, which examined six network options, was based on the options study by TM (Department of Transport, 1983d). This was made clear in the Serpell Report, which acknowledged that "our consultants ... developed and evaluated 6 network options" (1983, para. 13.16).

Drawing on the extensive input provided by the consultancy firms, the Serpell Report attempted to purify British Rail's finances by arguing that the nationalised industry was highly and persistently inefficient and had high costs, particularly in the areas of track mileage, employment and engineering. This 'impure' position was contrasted with a 'pure' position of improved finances which could be attained through reductions in lines, staff numbers and track maintenance costs (1983). The key drivers of change towards rail's purified finances would be the introduction of competition and partial privatisation. Hence, British Rail was strongly criticised for being "the only major railway in the world, other than in India", which manufactured its own rolling stock 
(Serpell, 1983, para. 7.6). This meant that most of British Rail's expenditure on the purchase and maintenance of rolling stock was paid to British Rail Engineering Limited, rather than to private sector suppliers. Despite accepting that British Rail's engineering subsidiary was competitive when producing high volumes of rolling stock, the Serpell Committee argued that costs would be reduced by fragmenting and privatising British Rail Engineering Limited, or by tendering for all new build contracts and contracting out repairs and maintenance work (Serpell, 1993, paras. 7.10, 7.30). The Serpell Committee demonstrated its ideological approach when it highlighted the "strong interest among some manufacturers" in obtaining a larger share of the rolling stock market (1983, para. 7.27). Its recommendations could be seen as calculated preludes to full privatisation.

Alongside the need for partial privatisation and competition, the Report provided TM's six options for rail's future, ranging from the maintenance of the existing network of 10,000 route miles (miles of train route with at least one track) to a drastic reduction to an unsubsidised network of 1,630 route miles (Serpell, 1983, Part II, chaps. 13,14). Whichever option was selected by government, the Report adopted PMM's approach and highlighted the need for significant reductions in the workforce, given that a "one per cent reduction in the present wage bill improves the railway's finances by about $£ 14$ million" (Serpell, 1983, para. 9.13). Further, the Report accepted TM's argument that, however many lines were kept open, there was scope for significant savings by reducing routine track maintenance work to "the lowest level of maintenance consistent with maintaining safety" (Serpell, 1983, para. 6.17). The overwhelming thrust of the Report was the need for cost savings, with only two of its 96 pages devoted to how revenue might be increased. Although the Report argued that there was "little scope" for 
increasing revenue from fares (Serpell, 1993, para. 5.1), this pessimism was soon to be contradicted as the economy recovered from recession and passenger miles increased by 26\% between 1982 and 1988/89 (Gourvish, 2002, p. 443).

\subsection{Responses to purification attempts}

To explore the responses to the attempts of the Serpell Committee to radically reform British Rail's structure and finances, the reactions of the other key actors in the reform and eventual privatisation of British Rail are examined: British Rail itself, members of the House of Commons and the House of Lords, the Treasury, and the Conservative Government. British Rail's Board had hoped for a report supporting a case for additional infrastructure expenditure, but was faced with a document arguing for substantial reductions in engineering costs. Hence, when confronted with the extreme recommendations of the Serpell Committee for line closures, the Board sought to enrol allies to its cause to challenge the Report's knowledge claims by orchestrating leaks, before the full Report was published, which "focused media attention on the more draconian prescriptions offered for the network" (Gourvish, 2002, p. 178). The British Rail Board, chaired by Peter Parker, then formulated its response, which was published with the Serpell Report. This accepted that improvements could be made to engineering, but criticised Serpell for providing unreliable information and for making few specific recommendations, instead focusing on broad headline recommendations (Gourvish, 2002, p. 179).

Very quickly, British Rail successfully enrolled many allies in a network in opposition to Serpell. Newspapers attacked the Serpell Report, providing headlines 
including "Heading for buffers" and "A really rotten report" (Gourvish, 2002, p. 179). Simon Jenkins, a journalist and non-executive director of British Rail, attacked Serpell in The Observer. There were very critical responses to Serpell in debates in both Houses of Parliament. In the Commons, criticism came not only from the Labour Party, but also from Robert Adley, a Conservative MP with a deep understanding of rail. Adley condemned the report as "useless as a basis for decisions about the future" of the railways. He suggested that consultants from the Australian offices of TM were not "the best people" to report on the UK's rail system, and argued that British Rail's "subsidy" should be regarded as "investment" in infrastructure (Adley, 1983). In the Lords, criticism was led by Lord Marsh, a former Chair of British Rail, who condemned the report as being of "no value whatsoever" in determining "what we want from the railway" (Marsh, 1983). He also commented acerbically on Serpell's conflict of interest, arising from the outsourcing of consultancy work to firms providing senior partners who were members of the Committee, arguing that it resembled " inviting the Kray family to pass judgement on the twins" (Marsh, 1993). Further rebukes to Serpell came from the Transport Select Committee, which, amongst many criticisms, highlighted the inclusion of the extreme network options as "positively unhelpful", and reproached Serpell for using firms seconding senior partners to the Committee as consultants (Transport Committee, 1983, paras. 20, 22-23). There was thus a keen awareness of the intentions of the government in creating a committee dominated by representatives of firms which might stand to gain great advantage from privatisation.

An internal ministerial group (MISC 94) was established in March 1983 to consider the Report but, with a general election pending, the political fall-out of "a sharp 
cut in the railways was judged too risky" (Parker, 2013, p. 314). The Treasury submitted an influential paper to MISC 94, which, contrary to its later views, argued against full or partial privatisation of British Rail. The stated reasons included that the railways "can never be entirely free from financial support from government", and that the railways were considered to be "a large and complex system with many joint costs and interdependence of different services: hence it cannot easily be broken into separate elements" (Parker, 2013, p. 314). Despite these concerns, a Cabinet colleague with strong neoliberal instincts tried to raise the issue of rail privatisation with Prime Minister Margaret Thatcher but was bluntly rebuffed by the prediction that it would become the government's "Waterloo" (Wolmar, 2005, p. 50).

Although British Rail successfully resisted Serpell's most extreme options for line closures, thus destroying some of the Report's knowledge claims, it had not won the case for substantial infrastructure investment and faced a Conservative Government determined to impose "harsh economic disciplines" in the form of financial objectives which were "progressively tightened" (Dent, 1991, p. 714). While the consultants may appear to have produced an unsuccessful attempt at purification, British Rail undertook two major internal reorganisations in order to inject business criteria into a wide range of important decisions. The first of these, the origins of which predated Serpell, involved a deliberate attempt to challenge British Rail's dominant "railway culture". This culture incorporated "a bureaucratic organization with a heritage of railway engineering and public service", where the network was still run by Regional General Managers (Dent, 1991, p. 714). The first reorganisation involved the appointment of Sector Managers, and the injection of business criteria into a much wider range of decisions affecting rolling 
stock, infrastructure and administration (Gourvish, 2002, pp. 106-150). The Sector Managers contributed to the development of a counter "business" culture which "cascaded across the senior management elite to become dominant" (Dent, 1991, p. 724). This initiative was developed "largely independently of political ideas", its private sector leanings owing more to the advice of "business consultants than to any political agenda" (Dent, 1991, p. 728).

The second major reorganisation, Organising for Quality, which came after Serpell, culminated in the elimination of British Rail's traditional regional structure and the division of staff among sectors, consisting of six businesses and 27 profit centres (Gourvish, 2002, pp. 374-383). This culminating change "represented the full flowering of the business-led, sector management concept" (Gourvish, 2002, p. 383). Alongside these home-grown structural and cultural changes, Serpell's influence was apparent, however, as extensive productivity gains were made through substantial reductions in the number of employees, a policy which the Report had strongly advocated. The number of employees declined by $30 \%$ in the 1980s, and then by an additional $12 \%$ in the early 1990s (Gourvish, 2002, pp. 270-276; 291-294). These redundancies were reflected in British Rail's improved financial performance, such that before privatisation it appeared to be one of the most financially successful railways in Europe with a subsidy of only 0.16\% of GDP compared to the European average of 0.52\% (Harris and Godward, 1997, p. 52). These apparent improvements, however, were problematic. Market share was sacrificed as fares were raised most years by more than the rate of inflation, and expenditure on the network, although improving, was insufficient "to reverse a long-term record of net disinvestment" (Gourvish, 2002, p. 230). 
The most important long-term consequence of the purification attempts of Serpell was to arrive in the 1990s. In the early 1980s, British Rail's privatisation was "inconceivable" (Dent, 1991, p. 727), and the Thatcher Government's caution in the election year of 1983 meant that Serpell's most radical proposals were not pursued. The development of the business culture, which was seen by British Rail's management "as a home-grown solution to governmental attack", arguably, however, "created preconditions for the discussion of privatisation" (Dent, 1991, pp. 727-728); for the "crafted accounts representing the railway as a series of businesses ... permeated through management structures and systems to operations on the ground. The railway ... has become its businesses" (Dent,1991, p. 729). As Hood noted (1995, p. 107), NPM has been adopted in some countries to avert the adoption of the full "New Right agenda for privatization", but in other cases it has been "the first step towards realizing that agenda". The task of realising the agenda of rail privatisation, which is examined in the next section, was taken up by Margaret Thatcher's successor.

\section{Phase 2: Purification of rail privatisation}

\subsection{Purification process}

It was Margaret Thatcher's supposedly more "moderate" successor as Prime Minister, John Major, who introduced the privatisation of Britain's last remaining nationalised industry. Citing the need to raise revenue, to reduce rail's subsidy, and to introduce competition, the Major Government, emboldened by consultancy reports commissioned near the end of the Thatcher Government, embarked on the riskiest and most ideological privatisation to date (Gourvish, 2002, pp. 383-491; Wolmar, 2005, pp. 
48-98). Rail was a very unpopular privatisation, the introduction of which was not inevitable. Widespread criticism of the privatisation proposals developed, encouraged by the media and reflecting opposition from rail and public transport lobby groups, the rail trade unions, the Labour Party, and some Conservative backbenchers. The criticism was crisply encapsulated by the prophetic warning of "a Poll Tax on wheels" (Adley, 1992), delivered by a leading Conservative critic, which was widely quoted by opponents of privatisation. Given this substantial opposition, the Major Government needed to rely on skilled allies to establish networks of support in order to transform the contested neoliberal values underlying rail privatisation into knowledge claims.

From the Conservative Government's perspective, useful allies had emerged from think tanks which, in the USA and Britain, have been very influential in developing applications of the neoliberal ideology. In 1985 Britain's Adam Smith Institute, an influential think tank espousing free market ideas which was founded in 1977, suggested privatisation by a process of fragmenting the integrated railway. This suggestion was later developed into two influential Institute publications, The Right Lines and Track to the Future, which developed the controversial proposal, later to be adopted as the model for rail privatisation, to create an infrastructure authority which would be separate from franchised train operating companies (Irvine, 1987, 1988). (Their author, Irvine, provided further assistance to the Conservatives by contributing to the rail privatisation proposals in their 1992 election manifesto). Neoliberal think tank opinion was not, however, unanimous. At a Centre for Policy Studies conference in 1988, for example, it was presciently argued that the proposed fragmented privatisation model, with a monopolist track authority charging operators for network access, could lead to a poorer quality of 
service as it would be remote from customers, lack incentives to pursue efficiency, and might allow infrastructure assets to deteriorate (Murray, 2001, p. 11).

The critique presented at the Centre for Policy Studies conference was in line with British Rail's viewpoint. Transport Secretary MacGregor held two meetings with British Rail's senior management. The first was with British Rail's Chair, Reid, and Chief Executive, John Welsby, followed by a second meeting with British Rail's 27 senior managers. All of the British Rail staff strongly opposed the proposal to separate the track from operations. Not only was this professional advice ignored, British Rail's position was regarded as obstructive and so it was excluded "from the policy-making arena", denied access to some of the consultancy reports (Dudley \& Richardson, 2000, p. 224) and, hence, had limited ability to influence the networks supporting privatisation. This clearly established that privatisation was to be achieved, all that had to be decided was how to bring it about and how to undermine the credibility of British Rail's expertise with the least political damage to the government. The solution to both problems was to rely on allies from a range of consultants, often from the Big 5 accounting firms. A "staggering" $£ 450$ million was spent on consultants, many of whom had no prior knowledge of the rail industry, in preparing for privatisation (Wolmar, 2005, p. 68). This figure represented one eighth of British Rail's pre-privatisation annual revenue. Table 1 shows some of the consultants' extensive involvement in planning and implementing rail privatisation. As well as making crucial contributions to planning the privatisation model, accounting consultants actively participated in developing the privatised industry. Jim Butler, a member of the Serpell Committee, for example, was appointed to the British Rail Board in 1994 to facilitate its privatisation (Gourvish, 2002, p. 421). 


\section{TABLE ONE ABOUT HERE}

Consultants were commissioned to report on "how and when" British Rail should be privatised (Department of Transport, 1991, p. 1), and so their reports became key purifying devices especially given the level and volume of opposition to privatisation. An analysis of structural options by accountants Deloitte, Haskins \& Sells (DHS) established knowledge claims which were confirmed by later consultancy reports. There was a "collective process of validation" as the reports accumulated, which was significant in "the construction of networks of support around claims to expertise" (Gendron et al., 2007, p. 101). These claims focused on the option involving a track authority and franchised train operators as it would encourage "competitive pressures" in bidding for franchises, which would bring efficiency gains in the form of cost and subsidy reductions (British Railways Board, 1989a, para. 466). DHS favoured as much competition in the privatised rail industry as possible, arguing that this would encourage the greatest “efficiency improvements” (British Railways Board, 1989b, para. 264). The analysis was very theoretical, however, even citing the "survival of the fittest" argument where "inefficient" companies go out of business, without explaining how this could apply to a public service (British Railways Board, 1989b, para. 262). The analysis of the fragmented model was similarly optimistic in its consideration of the impact of privatisation on safety, which was argued to be "straightforward" as a "single chain of command" could be established through the track authority which would be responsible for the safety of both the infrastructure and the train operators (British Railways Board, 1989b, paras. 231, 232). Further optimism was displayed by the proposal to improve the quality of 
passenger services by making quality "a condition of subsidy" (British Railways Board, 1989c, Table 7.1, p.3).

The knowledge claims provided by the DHS report were reinforced and supplemented by claims in other consultancy reports, such as that of the engineering consultants Putnam, Hayes \& Bartlett (PHB). The PHB report concurred with the claims of the DHS report, and argued that regulation would ensure that the track authority used the access charges paid by train operators to invest in order to maintain and enhance "the capacity of the infrastructure" (Department of Transport, 1991, p. 74). The neoliberal optimism which underlay this model was highlighted by the fact that the PHB report acknowledged that there were "no British or overseas examples" of such a track authority (Department of Transport, 1991, p. 45). The knowledge claims provided by consultancy reports were employed by the key consultant at the heart of rail policy-making, Sir Christopher Foster, senior partner with Coopers and Lybrand, who became special adviser to the Transport Secretary from April 1992 to November 1993, and later a nonexecutive director of Railtrack. He distilled the work of consultants into four key knowledge claims in the rail privatisation White Paper, New opportunities for the railways (Department of Transport, 1992). These claims were that the privatised railway, with the aid of regulation, would: ensure that investment continued to maintain and improve the railway; reduce costs and subsidy; maintain safety; and lead to a higher quality of service.

Foster's neoliberal defence of rail privatisation was later published in a Discussion Paper (Foster, 1994). Foster argued in very partisan, ideological terms that privatisation would "release energy and a positive attitude to change", and provide 
incentives to improve efficiency (Foster, 1994, pp. 2, 3). The core neoliberal proposition was that devolving British Rail's role to around 100 separate companies would "replace command relationships" by "contractual relationships between free-standing autonomous bodies" (Foster, 1994, p. 5). Foster argued that the key contractual relationship would be between the track authority and the train operators in the vertical separation of the rail industry. His defence of this radical change, which completely ignored the gains from British Rail's decade of reorganisations, was that the industry's command relationships were "complicated, inefficient, ineffective and bureaucratic" (Foster, 1994, p. 7). Ironically, as section 6 will demonstrate, these charges would prove to be a far more accurate description of the contractual relationships under privatisation.

By employing consultants who were accountants to develop the complex privatisation model, the Major Government used accounting's legitimacy to attempt to "depoliticise", and so purify, its unpopular and highly ideological activities (Catchpowle et al., 2004, p. 1053). For the supporters of such ideological activities, however, the use of consultants in this way represented a triumph. Madsen Pirie, founder of the Adam Smith Institute, argued that everyone "noticed the privatisation of the large-scale industries and utilities, but few people have noticed that policy formulation itself was privatised" (Pirie, 1993; cited by Ward (1993, p. 305)). The further opportunities for consultancy earnings from the policy formulation involved in BR's privatisation were highlighted the next year by Management Consultancy magazine, whose triumphalist article "On a Fast Track to Fee Income" was the subject of a critical House of Commons motion sponsored by Brian Wilson, Labour's Shadow Transport Minister. The motion on consultants and rail privatisation argued: 
That this House notes the article in the current issue of Management Consultancy magazine ... which predicts that the splintering of BR will provide consultants with a gravy train of considerable length ... further notes that Sir Christopher Foster, Coopers and Lybrand partner ... formerly adviser on rail privatisation to the Secretary of State for Transport before (being) ... appointed to the board of Railtrack, is quoted in support of the gravy-train thesis ... and believes that the British public would prefer investment in real trains to sponsorship of gravy trains operated by the Government's friends in the consultancy industry... (Wilson, 1994).

There was a crucial difference between the reactions of a key actor, the Treasury, to the Serpell Report and to the full privatisation proposals. While the Treasury had originally been very cautious about introducing radical changes to British Rail, a decade had passed which had included the privatisation of large, complex industries such as gas, water and electricity. Neoliberal ideas had permeated the state, and its champions now occupied senior positions in the civil service. A very influential figure was Steve Robson, who led the privatisation drive as head of the Treasury's privatisation unit. The Treasury's revised view was that rail's fragmentation and privatisation would enable a reduction in subsidy, through the introduction of competition, and Robson "played the key role" in driving through the fragmented privatisation model which was adopted (Wolmar, 2005, p. 53).

Of the key actors involved in rail privatisation, British Rail had been excluded from full access to the policy making network, while the Conservative Government ensured that it had the strong support of consultants and the Treasury in a "stable and solid" network (Gendron et al., 2007, p. 105). The role of consultants was crucial in serving "the knowledge needs" of those holding "positions of political power within the state apparatus" (Saint-Martin, 1998, p. 348). Despite its limited access to the privatisation network, British Rail's Board and the majority of senior managers, most of 
whom "would have been far happier to run with a private, but vertically integrated industry" (Gourvish, 2002, p. 433), attempted to oppose the fragmented privatisation model. British Rail's Chair, Sir Bob Reid, attempted to raise problems with the proposed model in a prescient letter sent to the (then) Transport Secretary, Malcolm Rifkind in April 1991, which pointed out the "complexity" of fragmenting the railways; the "strange looking" privatisation which would depend on "continued subsidy"; and the danger to safety posed by the "radical reorganisation" (British Railways Board, 1991).

These knowledge claims, which drew on BR's expertise and that of its own consultants, made no discernible impact on the privatisation networks which continued to support the fragmented model. This is demonstrated by the briefing note, prepared for the British Rail Chair's meeting with Malcolm Rifkind's successor as Transport Secretary, John MacGregor, when the privatisation White Paper was published 14 months later. The briefing note emphasised similar points to the 1991 letter, highlighting "points of major concern" with the fragmented privatisation model (British Railways Board, 1992a, introduction). It accurately predicted that the track access charges paid by operating companies would lead to increases in both costs and subsidy, and that there could be difficulty in maintaining safety standards (British Railways Board, 1992a, notes $2,4)$.

British Rail's briefing note drew partly on the work of its consultant Professor Bradshaw, a transport expert, who prepared a critical analysis of the fragmented privatisation model proposed by consultants PHB. Bradshaw's prescient critique foresaw that tendering for the maintenance of the infrastructure assets carried "a great danger of asset rundown" (Bradshaw, 1991, p. 3). Further, Bradshaw, crucially, highlighted the risk 
that the track access charges to operators might not "cover costs" for the infrastructure authority, and raised serious doubts about how the "capital market disciplines would work" with the monopolist track authority (Bradshaw, 1991, pp. 5, 7, 10).

Having established a stable network of support for privatisation, the government was sufficiently confident to ignore the knowledge claims of BR and its consultants. It was still necessary for Parliament to approve the privatisation legislation, in the form of the 1993 Railways Bill. This was not certain as opposition to rail privatisation included the Labour Party and some Conservative MPs, led by Robert Adley, and votes in both Houses of Parliament were often "uncomfortably close" (Gourvish, 2002, p. 433). Adley was a prominent member of the Save Our Railways campaign group, established to oppose rail privatisation, and chaired the Transport Select Committee. The Conservativedominated Committee conducted a detailed examination of the 1993 Railways Bill and in April 1993 produced a unanimous critical report emphasising the risks involved in rail privatisation. Presciently, it warned of the risks involved in relying on private sector investment, the danger that costs and subsidy would rise, and the problems of maintaining safety standards (Transport Committee, 1993, paras. 367, 501, 474). The Conservative Government was able to protect the ideological core of its proposals by arguing that, despite these warnings, the Transport Committee had not opposed rail privatisation in principle. Further, Adley died the month after the Committee's report was published, and the campaign against privatisation lost momentum. The Railways Bill was subject to many amendments, but the Major Government secured its passing into law in November 1993. 
The contribution of consultants extended way beyond policy formulation to assisting in the implementation of the privatisation model. Railtrack's structure, role and job descriptions were devised by management consultants McKinsey, who categorised the role of the Chief Executive as ensuring that the company optimised " the value of its network and assets", and highlighted two "core railway capabilities" as "maintaining the network" to maximise its value and "exploiting property for maximum value" (British Railways Board, 1992b, Appendices B5, C21). Extensive work on rail's cost structure, the fault attribution framework, and access charges was undertaken by Coopers and Lybrand and Touche Ross (Department of Transport, 1993, p. 1; Department of Transport, 1995, pp. 6, 7).

As rail privatisation became increasingly certain, there was a range of views on its likely success across the media. Newspapers with a free market focus generally welcomed rail privatisation in principle but predicted that there could be problems in practice. The Times, for example, argued that the policy implementation was likely to be "desperately muddled" unless British Rail were allowed to run some franchises (Editorial, 1993). A leading critic was the transport correspondent of The Independent, Christian Wolmar, who argued presciently that rail privatisation would lead to increased costs and subsidy (1993), and continued to campaign against the fragmented structure in both newspaper articles and a very critical book (2005). Opinion polls revealed a majority of the public remained consistently opposed to rail privatisation, opposition which was highlighted in Parliament by the Labour Party (see, for example, Clinton-Davis, 1995). 


\subsection{Privatisation of British Rail: The triumph of purification}

The key consequence of the purification process was the splintering of the integrated structure of British Rail. Despite their opposition to the fragmented model, British Rail's Board and senior managers worked hard to dismantle the structure established under the Organising for Quality reforms, which had only just been completed in 1992. The pressure on many key managers was "intense", and the railway's punctuality performance deteriorated as staff had to keep train services running while restructuring the industry (Gourvish, 2002, pp. 442-443). Railtrack, the infrastructure owner, was privatised in 1996, and by the next year all the rail businesses had been sold and an "unparalleled" degree of fragmentation had been introduced into the industry (Nash, 2000, p. 166). The privatisation of British Rail was now complete, demonstrating the triumph of purification.

The system was divided into around 100 components, which included: Railtrack; 25 franchised passenger operating companies (TOCs) selected in a competitive bidding process; three rolling stock companies (ROSCOs); 13 infrastructure companies; six freight companies (soon reduced to two); and some support companies. This increased complexity of rail was reflected in its regulatory system, which included two new bodies: The Office of the Rail Regulator (ORR) (later renamed the Office of Rail Regulation), and the Office of Passenger Rail Franchising. The former body supervised Railtrack, while the latter allocated franchises, dispensed subsidies and monitored the TOCs' performance. The ORR's key regulatory task was periodically to set the level of track access charges, which would be paid to Railtrack by the TOCs. The level of access charges was crucial both for Railtrack's profitability and for the viability of the TOCs, 
most of which were unprofitable and, contrary to the optimism of the neoliberals, continued to depend on subsidy, even though the subsidy was only intended to be temporary. In 1999/2000, for example, the TOCs received $£ 1.4$ billion in subsidy, which underpinned their payment to Railtrack of $£ 2.2$ billion in access charges, charges which represented $85 \%$ of the company's total income.

A major consequence of the purification process was the changed attitude of the Labour Party, which originally opposed privatisation on principle and called for the renationalisation of industries, including rail. Gradually, however, the approach of senior figures in the Labour Party towards privatisation began to shift. Tony Blair, elected as leader in 1994, persuaded the party to rewrite Clause IV of its constitution, replacing the "common ownership" of the means of production, distribution and exchange with an emphasis on "the market" and "a thriving private sector" (Toye, 2004, pp. 92-93). Labour Party members accepted this ideological shift for several reasons. Many were demoralised by the combined impact of three further Conservative election victories since Margaret Thatcher's election in 1979, and the decreased union membership during the 1980s heightened the need to attract donations from business (Toye, 2004, p. 99). Following the rewriting of Clause IV, "a new perspective began to influence transport policy" and Labour's 1997 election manifesto argued that rail must be run in the public interest with higher levels of investment (Jupe, 2009a, p. 715). Despite the many cogent criticisms which Labour and other opponents had previously levelled at rail privatisation, the knowledge claims produced by the consultants became the accepted truth. Underlying this purification of the party's policy on rail privatisation was the neoliberal political 
settlement of Reagan and Thatcher, "which became a legacy that a subsequent generation of political leaders found hard to dislodge" (Harvey, 2007, p. 62).

\section{The knowledge claims and outcomes of rail privatisation}

This section deconstructs the key knowledge claims of the proponents of rail privatisation. It has been established that these claims were successful in their purification attempts, as rail privatisation was implemented despite significant opposition. The experience of rail privatisation, however, may be employed critically in order to transform the apparently purified position into one where impurities can be highlighted. This analysis builds a detailed case against the fallacy of the key knowledge claims involved in the neoliberal rhetoric employed by the supporters of rail privatisation. A significant part of the success of the consultants in formulating rail privatisation policy derived from their ability to counter the expertise of opponents, particularly British Rail, who predicted the key problems which would arise from adopting the fragmented model. Hence, the four key knowledge claims produced in the 1992 White Paper are examined below, in the light of the outcomes of rail privatisation, in order to expose the flaws of the privatisation model.

\subsection{Invest to maintain and improve the network}

In the 1992 White Paper it was argued that the government "wants to ensure that Railtrack continues to invest to maintain and improve the network", and that investment would largely be financed from access charges (Department of Transport, 1992, para. 43). However, consistent with its profit-maximising status, Railtrack's initial focus was 
on shareholders and infrastructure expenditure was neglected. Maintenance and renewals work was outsourced to 13 infrastructure companies, which employed extensive subcontracting and replaced experienced staff with untrained, or poorly trained, casual workers (Cole and Cooper, 2006, pp. 617-621). Moreover, despite the complexity of Railtrack's infrastructure, there was no comprehensive asset register showing the network's condition. This was vital for Railtrack had implemented "Project Destiny" which was developed by McKinsey. This was a complex risk-based maintenance system, which aimed to save money by assessing the network's assets in order to maximise their use. Hence, assets would only be renewed when they became life-expired, rather than following the traditional policy undertaken by British Rail and other European railways of replacing assets at set time intervals. Heavily used points, for example, should have been "replaced more often than those on less busy routes" (Wolmar, 2005, pp. 170).

The adverse and predictable consequences of this policy led by consultants, who were not recognised experts in rail services and management, were that Railtrack neglected what should have been its core function, the maintenance and renewal of the rail infrastructure. The network infrastructure was not given visibility in the new priorities and, as the NAO (2000, para. 17) forecast, there was a decline in the "health of the network". This decline was tragically demonstrated by the Hatfield accident in October 2000, which resulted in four people being killed and 70 injured. Hatfield may be regarded as "the epitome of the failings" of rail privatisation (Wolmar, 2005, p. 156). The accident was caused by a faulty rail which had been discovered 21 months earlier, and earmarked for renewal, but not replaced because of Railtrack's very poor management of contractors. Lacking an asset register, Railtrack was unable to establish whether there 
were more broken rails in the system. Its alternative, which plunged the company into what proved to be a terminal crisis, was to introduce over 1,000 speed restrictions in an attempt to remedy the accumulated maintenance and renewals deficit (Jupe, 2009b, p. 184). In October 2001, faced with increasing demands for subsidy, Transport Secretary Byers obtained a court order placing an insolvent Railtrack in administration.

The Labour Government rejected renationalisation, and protected the neoliberal core of the privatisation model by placing Railtrack in administration for one year (Wolmar, 2005, p. 213) and developing a replacement company. Network Rail, which replaced Railtrack in October 2002, was established as a not-for-dividend "public interest company" limited by guarantee. It has members rather than shareholders and is financed by private debt rather than equity. Not surprisingly, private advisers contributed to Network Rail's creation. One was Grayling, a senior research fellow at the Institute of Public Policy Research, who argued that an evolutionary approach was needed which both removed shareholder influence and avoided renationalisation (Grayling, 2001). Another influential figure was Shriti Vadera, a former investment banker, who was special adviser to the Chancellor of the Exchequer Gordon Brown (Wolmar, 2005, p. 212).

Network Rail's combination of debt finance and large subsidy, the very weaknesses which British Rail was criticised for, has enabled significant increases in infrastructure expenditure. Under Railtrack's stewardship, capital investment in the network was neglected in the first two years after privatisation, while the company focused on a profit-maximising agenda. British Rail's capital investment had averaged $£ 840$ million per year in the pre-privatisation period 1988 to 1994 (Gourvish, 2004, p. 
304), a figure which, unlike the infrastructure investment of its successor companies, was not inflated by the profit margins on outsourced contracts. After privatisation, as Table 2 demonstrates, capital investment had declined to $£ 484$ million in $1996 / 97$, increasing to only $£ 599$ million in $1997 / 98$.

\section{TABLE TWO ABOUT HERE}

\subsection{Reduction of costs and subsidy}

The White Paper's neoliberal rhetoric claimed that rail privatisation, by introducing competition and business efficiency, would "reduce costs" (Department of Transport, 1992, para. 19). Cost reductions were expected to eliminate public subsidy in the long run, and then to produce net payments to the government from TOC franchisees operating "profitable services" (Department of Transport, 1992, para. 21). In practice, however, privatisation led to a very substantial increase in both costs and subsidy. The key additional costs may be summarised as interface costs and cash leakages (Harris and Godward, 1997, p.107). Interface costs arise as a result of many companies being involved in a supply chain, which creates an upward pressure on prices as each company seeks surplus value in the form of profit. Cash leakages arise as interest payments and dividends are required to finance debt and equity respectively.

The key interface costs introduced by privatisation were track access charges and leasing charges for trains. The two represented the bulk of the costs of the TOCs, and constituted most of the revenue of Railtrack and the ROSCOs respectively. These interface items alone added $£ 3$ billion per year to the costs of the privatised railway (Jupe, 
2009a, p. 717). In addition, the outsourcing of Railtrack's maintenance and renewals work meant it was necessary to reward layers of contractors. The dramatic increase in rail costs since privatisation can be demonstrated by comparing British Rail's total operating costs before privatisation with those of the privatised railway. British Rail's revenue in 1993/94, the year before its reconstitution as an infrastructure provider, was $£ 3.6$ billion, which broadly equated with the $£ 1.8$ billion cost of running the infrastructure, along with the $£ 1.8$ billion cost of freight and passenger services (British Rail, 1993/94). In 1999/2000, Railtrack’s costs of $£ 2.4$ billion were two thirds of British Rail's costs of $£ 3.6$ billion in 1993/94, but the company only had responsibility for half of its predecessor's activities. By 2012/13, the comparable figure for the costs of the privatised infrastructure authority had risen to $£ 5.5$ billion. Hence, rail's infrastructure costs have tripled since privatisation, with the key driver being substantial interface costs.

The substantial increase in infrastructure costs under Railtrack and then under its successor is revealed in Table 3.

\section{TABLE THREE ABOUT HERE}

The consultants' knowledge claims accepted that the TOCs would be subsidised after privatisation, but this subsidy, it was confidently predicted, would progressively decline and then be eliminated. In practice, the substantial cost increases mean that Network Rail has also been subsidised, alongside the TOCs. Table 4 shows the increased public support for the rail industry from 2001/2002. This clearly exposed the deceptive claims of the consultants that subsidies would be abolished in the long run with 
privatisation, that the profit driven companies which would replace British Rail would operate more efficiently.

\section{TABLE FOUR ABOUT HERE}

In order to protect the TOCs, whose profitability even with subsidy was fragile, the track access charges were reduced to around $£ 1.5$ billion in most years and Network Rail became heavily dependent both on government grants and private debt. Privatisation's introduction of private sector debt and equity produced huge cash leakages. Table 5 shows the increased cash leakages and debt of the infrastructure provider since privatisation.

\section{TABLE FIVE ABOUT HERE}

The leakages of dividends and interest over the period 1994/1995 to 2012/2013 totalled $£ 10.2$ billion. Railtrack distributed dividends totalling $£ 709$ million between $1995 / 1996$ and $2000 / 2001$, equivalent to $41 \%$ of the total operating profits of $£ 1.7$ billion generated over the period. The most significant leakages, however, are interest payments which have risen by over $£ 900$ million since privatisation. This reflects the increase in debt of $£ 28$ billion since privatisation, reaching $£ 30.4$ billion by $2012 / 2013$. The most significant increase in debt has occurred under Network Rail's stewardship. Indeed, NetworkRail’s £3 billion increase in debt during 2012/2013 was greater than British Rail's total borrowing of $£ 2.5$ billion in 1993/1994 to fund all aspects of its operations.

Although Network Rail has brought maintenance work in-house, around $75 \%$ of infrastructure expenditure is still outsourced. The additional costs incurred by Network 
Rail, arising from its private sector borrowing and outsourcing of renewals and enhancement expenditure, are summarised in Table 6.

\section{TABLE SIX ABOUT HERE}

\subsection{Maintain safety}

Safety, according to the 1992 White Paper, "would be maintained" across the privatised railway (Department of Transport, 1992, para. 76). Contrary to these blithe assurances, tragically privatisation in practice had very serious repercussions for the rail network as safety became subservient to the pursuit of profit. British Rail had been staffed by an integrated workforce which developed a "culture in which safety was nurtured as a habit of thought" (Terry, 2001, p. 5). Inspectors were employed by British Rail to cover all aspects of its work and major improvements in safety resulted from swiftly and uniformly applying lessons learned from accidents and through investment in new safety measures. There were fewer deaths in railway accidents in each successive postwar decade: from 344 deaths in the 1940s, to 337 in the 1950s, with a dramatic reduction to 95 in the 1980s, and just eight up to the year of rail's privatisation in 1996 (Wolmar, 2005, pp. 100-101).

Tragically, this safety culture was splintered and weakened by privatisation. Four major fatal accidents between 1997 and 2002 originated in the "the industry's fragmentation and the neglect of safety considerations between organisational boundaries" (Jupe and Crompton, 2006, p. 1060). In the Southall accident soon after privatisation in 1997, where seven people died and over 100 were injured, a Great 
Western passenger train smashed into a goods train crossing its path in West London. The underlying cause of the accident was the passenger train's non-functioning warning system, which had not been corrected at the maintenance depot which was badly managed and under-staffed following reorganisation demanded by the new private sector owners. The public inquiry found that this resulted in staff working under "more pressure" and a lack of attention to "safety-critical" details, problems compounded by the lack of co-ordination between Railtrack and Great Western trains over the reporting of faults in the train's early warning system (Uff, 2000, pp. 64, 68 and 145). The more serious accident at Ladbrooke Grove in 1999, when 31 people died and 425 were injured, occurred when an inexperienced Thames Trains driver ignored a red light and crashed into another passenger train two miles out of Paddington station. The public inquiry criticised both the weak training programme of Thames Trains, which was 10 weeks shorter than British Rail's, and Railtrack's inadequate procedures for dealing with repeated Signals Passed at Danger incidents (Cullen, 2001, pp. 61, 129).

The problems caused for safety in the fragmented rail industry were demonstrated most graphically by the train derailment near Hatfield, which has been discussed earlier. Although a huge effort was made to deal with the maintenance backlog after Hatfield, track maintenance problems were again highlighted in May 2002 by the fatalities at the Potters Bar derailment. A train from Potters Bar to King's Lynn derailed at a set of points near Potters Bar, killing seven people and injuring 76. The accident investigation established that the points failed as they were "not fit for purpose" (Health and Safety Executive, 2003, p. 6). 
Safety appears to have been given a higher priority under Network Rail and, as shown in Table 2, there has been a substantial increase in infrastructure expenditure. While the condition of the network generally has continued to improve, there was a serious train derailment at Grayrigg in Cumbria in 2007, when one person was killed and 22 injured, arising from a faulty set of points (Jupe, 2009a, p. 729).

\subsection{Lead to higher quality of service}

Privatisation, according to the 1992 White Paper, would lead to "a higher quality of service" for passengers (Department of Transport, 1992, para. 1). This was a very optimistic claim as British Rail's organisational reforms in the decade before privatisation

had enabled it to cope with rising passenger demand, as the economy slowly recovered from the recession of the early 1980s, while improving the quality of service in the form of punctuality. The performance of InterCity trains improved steadily, with the proportion arriving on time increasing from $77 \%$ in $1986 / 1987$ to $91 \%$ by $1993 / 1994$, and the proportion of all trains arriving on time averaging 90\% by 1993/1994 (Gourvish, 2002, p. 504). Under privatisation, as Table 7 reveals, overall punctuality declined initially from $89.8 \%$ in $1997 / 98$ to $87.8 \%$ in $1999 / 2000$.

\section{TABLE SEVEN ABOUT HERE}

This was followed by a striking fall in punctuality to $78 \%$ by $2001 / 2002$, which arose primarily from the Hatfield crash in October 2000 and its aftermath. It has taken extensive infrastructure work, underpinned by billions of pounds in capital grants, to gradually return punctuality to the pre-privatisation level, and then to reach performance 
levels of just over 90\% from 2008/2009. There are still significant variations in performance, however, with long distance operators lagging behind the others.

The foregoing analysis of four key privatisation knowledge claims has demonstrated the extent to which the claims were manufactured beliefs, co-produced by consultants with the client, the Conservative Government, "since consultant and client rely on each other" (Christensen and Skaerbaek, 2010, p. 543). The extent to which the claims were manufactured was exposed by Railtrack's collapse, the escalation of rail's costs and subsidy, and the safety and punctuality problems which arose. The consultants presented their knowledge claims with a missionary zeal, determined to act on neoliberal imperatives and setting aside any potential imperfections in the privatisation model, imperfections which had been highlighted by knowledgeable experts at British Rail.

\section{Conclusions}

This paper contributes to the literature on both neoliberalism and the role of consultants in public sector reforms. The case of British Rail's reform and privatisation demonstrates the extent to which the advocates of neoliberal ideology, including consultants and think tanks, have permeated the formulation of public policy in the British state. The belief that efficiency would be improved by separating infrastructure from operations, and fragmenting British Rail into 100 separate companies, relied heavily on neoliberal knowledge claims provided by consultants in purification attempts. Consultants made a very significant contribution to rail reform and then rail privatisation under the Thatcher and Major Governments "in the process by which networks of support develop around claims to expertise" (Gendron et al., 2007, p. 125). Their reports acted as key purification devices, legitimising disputed privatisation claims with the appearance of 
"disinterested and rigorous" expertise (Gendron et al., 2007, p. 127), despite the very obvious, publicly known, conflicts of interest arising from bringing consultants into policy making. Senior partners of the firms from which the consultants were recruited by the Thatcher Government were also made members of the Serpell Committee, and consultants were later brought into the heart of both planning and implementing rail privatisation under the Major Government.

There were several reasons for the success of the consultants in promoting their controversial knowledge claims. The Major Government regarded British Rail's opposition to the fragmentation and privatisation of the rail network as obstructive, and so British Rail was excluded from the policy-making arena and denied access to some of the consultancy reports. The Government then relied on skilled allies from consultancy firms to establish networks of support for rail privatisation. The consultants' outputs were "co-produced" with their client, the Conservative Government, and so became "a powerful element of the resultant purification" (Chstistensen and Skaerbaek, 2010, p. 531). The consultants were given crucial influence on policy-making by the initial tender documents whose visible agenda explicitly required consultants to report on how, rather than whether, British Rail should be privatised. Hence, "consultant and client" had to "rely on each other" (Christensen and Skaerbaek, 2010, p. 543). Further, consultants were intimately linked with the client through important secondments. Sir Christopher Foster, senior partner with Coopers and Lybrand, prepared the 1992 White Paper in his capacity as special adviser to the Transport Secretary, and was later appointed a nonexecutive director of Railtrack. Jim Butler, senior partner with KPMG, was appointed to British Rail's Board to facilitate the privatisation process. 
The failures of rail privatisation which led to "deadly muddle and confusion" (Harvey, 2007, p. 67), resulting most notoriously in the worst rail crashes for several decades, have ensured that it is still very unpopular. The purification attempts and the perceived veracity of the consultants' knowledge claims were so successful, however, that the Labour Government, elected in 1997, refused to consider Railtrack's renationalisation, despite evidence that this would be well received by the public. A Guardian/ICM poll in October 1999, for example, which predated the company's collapse by two years, revealed that over $70 \%$ of voters supported Railtrack's renationalisation (Travis and Wells, 1999). Railtrack's collapse provided the Labour Government with the perfect opportunity to renationalise rail, but it chose to protect the neoliberal core of the privatisation model by reconstituting Railtrack as a "public interest company", Network Rail. Over a decade later, after a major review of the rail industry, the Labour Party reaffirmed its policy as the maintenance of the neoliberal core of the industry. It made one concession, that not-for-profit companies would be allowed to bid for rail franchises alongside for-profit companies (Topham, 2014).

The approach of protecting the neoliberal core from criticism is widespread in Britain. Architects of rail privatisation, such as Steve Robson, have regularly attempted to protect the core of neoliberalism from criticism by classifying any problems as implementation flaws. A good example of this was given when he left the civil service, conceding in a newspaper interview that, although rail's fragmentation and privatisation was right, "we probably broke it into too many pieces" (Fagan, 2000). Further, the rail regulator suggested that a solution to Network Rail's increasing dependency on private 
debt was a partial reprivatisation of the infrastructure in order to attract private investment (ORR, 2013a, para. 2.26).

Consultants and think tanks provided expertise to justify both rail privatisation and the creation of Network Rail. Such expertise was supposedly delivered in the public interest rather than self-interest, but "expertise is always interested" and "produced to support the aims of some members of society" (Gendron et al., 2007, p. 127). Further, like Humphrey's study of the role of consultants in the introduction of financial management to the British Probation Service, this paper "raises questions" as to the nature of the "claimed bases of expertise" of the consultants, which were often derived from "faithlike assertions" (1994, p. 171). In the case of rail privatisation, these "faithlike assertions" were grounded in neoliberalism and given credibility by accounting discourses.

Consultants, particularly the accountants, have used their expertise to play a crucial role in privatisations, both in Britain and around the world, which have benefited the private sector. Rail privatisation, particularly in the form of Network Rail, is, in practice, an expensive mechanism for channelling large amounts of public money to private companies (Jupe, 2009a, p. 731). Critical accounting research, as this paper and others have demonstrated, can be used to "evaluate public policy decisions in terms of the distribution of resources to different social groups" (Shaoul, 2005, p. 468), and to make visible the extent to which flawed policies such as rail privatisation resulted from dogmatic and excessive neoliberal public policy formulation. In this way, accounting can play an educative role in demonstrating the need for a much broader input into policy 
formulation, including the possibility of a planned public transport system which is run in the public interest rather than for the benefit of private interests.

\section{Acknowledgements}

The authors would like to thank the Journal's Co-Editor Yves Gendron for his support and guidance throughout the revision process, and the two anonymous reviewers for their helpful comments. 


\section{Table 1}

Multiple consultancies involved in rail privatisation

Roles of Consultants

Advise on privatisation options

Advise on future structure of rail

Advise on track access charges

Advise on cost allocation

Advise on accountancy and tax issues

Advise on accountancy issues

BR board member to

facilitate privatisation process

Special adviser to Transport Secretary; non-executive director of Railtrack

Advise on sale of rolling stock companies

Advise on establishing Railtrack

Develop "Project Destiny" to reduce

Railtrack's network infrastructure costs

Recommend block signalling

system for Railtrack

Administrator for Railtrack after its

collapse into insolvency
Consulting firms

Coopers and Lybrand; Deloitte, Haskins \& Sells

Coopers and Lybrand; Deloitte, Haskins \& Sells; KPMG; Putnam

Hayes \& Bartlett

Coopers and Lybrand; Putnam, Hayes \& Bartlett

Coopers and Lybrand; Touche Ross

KPMG

Ernst and Young; Deloitte \& Touche

Jim Butler, KPMG

Sir Christopher Foster, Coopers and Lybrand

Price Waterhouse

McKinsey \& Company

McKinsey \& Company

Booz Allen \& Hamilton

Ernst and Young

Sources: Rail privatisation files at The National Archive (various years).

Gourvish (2002). 


\section{Table 2}

Capital investment under Railtrack and Network Rail

Renewals and enhancement expenditure

Railtrack

$\underline{\text { Year }}$

$\underline{£ \mathrm{~m}}$

$1996 / 97$

484

$1997 / 98$

599

$1998 / 99$

1,653

$1999 / 00$

1,847

$2000 / 01$

2,535

2001/02

1,557

April-Oct 02

1,500

Network Rail

$\underline{\text { Year }}$

$\underline{£}$

2002/03

1,654

2003/04

3,858

2004/05

3,598

2005/06

3,151

2006/07

3,326

2007/08

3,952

$2008 / 09$

4,743

2009/10

3,920

2010/11

3,997

2011/12

4,600

$2012 / 13$

5,050

Notes: 1. The figures for Network Rail for 2002/03 are for a six month period.

2. Capital investment includes renewals and enhancement infrastructure expenditure, all of which was outsourced to infrastructure companies by both Railtrack and Network Rail.

Sources: Audited Annual Report and Accounts of Railtrack and Network Rail. Nominal values, unadjusted for inflation. 


\section{Table 3}

Total costs and total revenue of Railtrack and Network Rail from 1999/2000 to $\underline{2012 / 2013}$

\begin{tabular}{lll}
\hline $\begin{array}{ll}\text { Total revenue } \\
£ \mathrm{~m}\end{array}$ & $\begin{array}{l}\text { Total costs } \\
£ \mathrm{~m}\end{array}$ & $\begin{array}{l}\text { Profit/(loss) } \\
£ \mathrm{~m}\end{array}$ \\
& & \\
\hline
\end{tabular}

$\underline{\text { Railtrack }}$

$\underline{\text { Year }}$

$\begin{array}{lccc}1999 / 00 & 2,547 & 2,389 & 158 \\ 2000 / 01 & 2,476 & 2,921 & (445) \\ 2001 / 02 & 2,912 & 3,981 & (1,069) \\ \text { April-September 02 } & 1,522 & 2,167 & (645)\end{array}$

Network Rail

$\underline{\text { Year }}$

$\begin{array}{cccc}2002 / 03 & 1,443 & 1,559 & (116) \\ 2003 / 04 & 2,606 & 3,340 & (734) \\ 2004 / 05 & 3,800 & 3,829 & (29) \\ 2005 / 06 & 3,837 & 4,090 & (253) \\ 2006 / 07 & 5,795 & 4,760 & 1,035 \\ 2007 / 08 & 5,960 & 4,771 & 1,189 \\ 2008 / 09 & 6,160 & 5,559 & 601 \\ 2009 / 10 & 5,668 & 5,384 & 284 \\ 2010 / 11 & 5,712 & 5,399 & 313 \\ 2011 / 12 & 6,004 & 5,243 & 761 \\ 2012 / 13 & 6,197 & 5,498 & 699\end{array}$

Note: The figures for Network Rail for 2002/03 are for a six month period.

Sources: Audited Annual Report and Accounts of Railtrack and Network Rail. Nominal values, unadjusted for inflation. 


\section{Table 4}

Government support for TOCs and Railtrack/Network Rail from 2001/2002 to $\underline{2012 / 2013}$

\begin{tabular}{lccl}
\hline & $\begin{array}{c}\text { Subsidies } \\
\text { to TOCs } \\
£ \mathrm{~m}\end{array}$ & $\begin{array}{c}\text { Capital expenditure grants } \\
\text { to Railtrack/Network Rail } \\
£ \mathrm{~m}\end{array}$ & $\begin{array}{l}\text { Total } \\
\text { support } \\
£ \mathrm{~m}\end{array}$ \\
\hline Year & & & \\
$2001 / 02$ & 1,037 & 499 & 1,536 \\
$2002 / 03$ & 1,239 & 792 & 2,031 \\
$2003 / 04$ & 1,773 & 1,448 & 3,221 \\
$2004 / 05$ & 1,267 & 2,058 & 3,325 \\
$2005 / 06$ & 1,211 & 1,985 & 3,196 \\
$2006 / 07$ & 1,769 & 3,397 & 5,166 \\
$2007 / 08$ & 1,433 & 3,673 & 5,106 \\
$2008 / 09$ & 554 & 4,266 & 4,820 \\
$2009 / 10$ & 766 & 3,564 & 4,330 \\
$2010 / 11$ & 156 & 3,492 & 3,648 \\
$2011 / 12$ & 83 & 3,745 & 3,828 \\
$2012 / 13$ & $(256)$ & 3,780 & 3,524 \\
\hline Totals & 11,032 & 32,699 & 43,731 \\
\hline
\end{tabular}

Note: The 2012/13 subsidies figure shows net payments by TOCs to government.

Source: ORR Government support to the rail industry, 2013b, p. 1. Nominal values, unadjusted for inflation. 


\section{Table 5}

Rail debt and cash leakages before and after privatisation

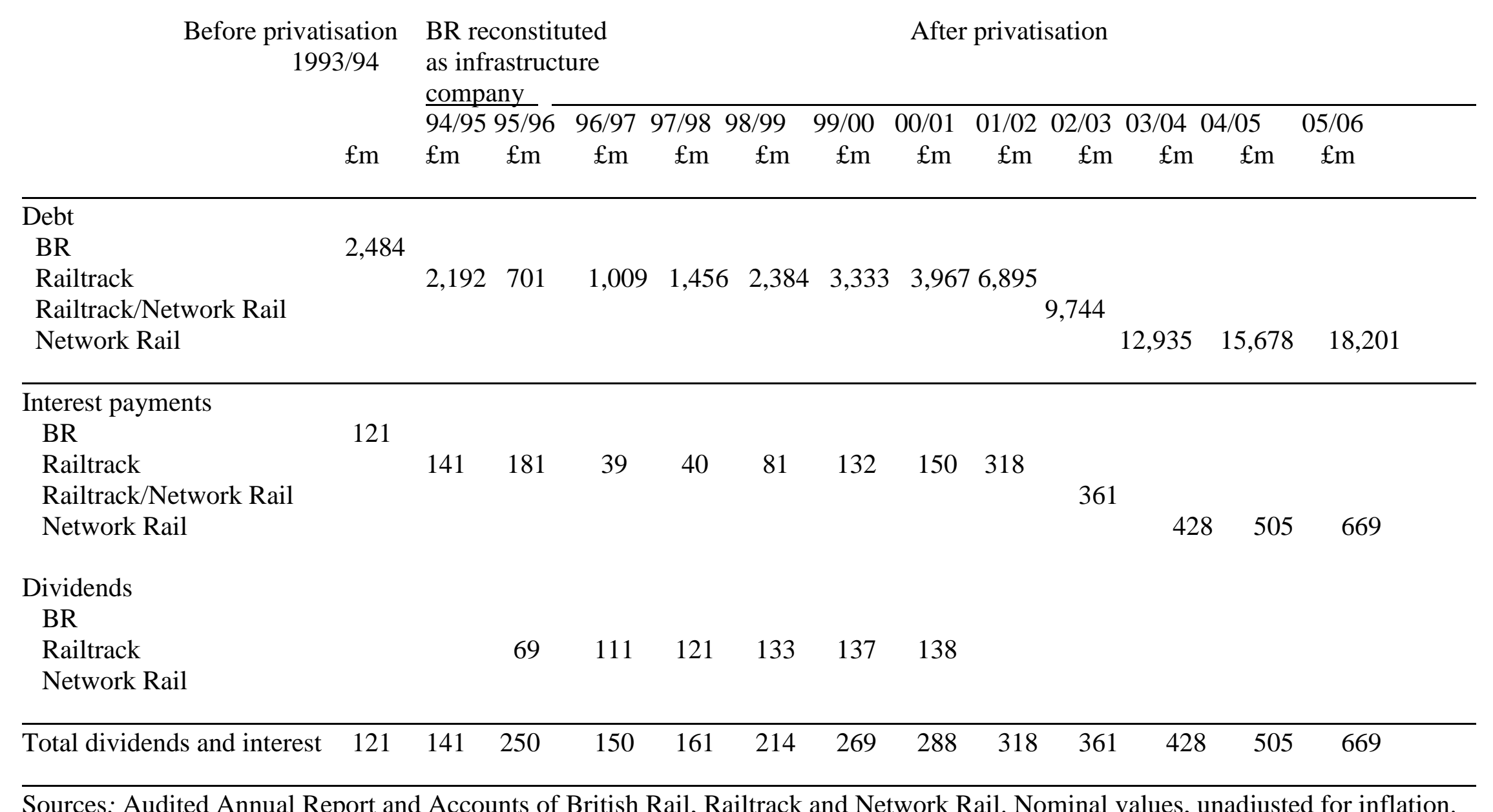

Sources: Audited Annual Report and Accounts of British Rail, Railtrack and Network Rail. Nominal values, unadjusted for inflation. 


\section{Table 5 (continued)}

$\underline{\text { Rail debt and cash leakages before and after privatisation }}$

After privatisation

\begin{tabular}{lcccccc}
\hline $06 / 07$ & $07 / 08$ & $08 / 09$ & $09 / 10$ & $10 / 11$ & $11 / 12$ & $12 / 13$ \\
$£ \mathrm{~m}$ & $£ \mathrm{~m}$ & $£ \mathrm{~m}$ & $£ \mathrm{~m}$ & $£ \mathrm{~m}$ & $£ \mathrm{~m}$ & $£ \mathrm{~m}$
\end{tabular}

\begin{tabular}{|c|c|c|c|c|c|c|c|c|}
\hline $\begin{array}{l}\text { Debt } \\
\text { BR } \\
\text { Railtrack } \\
\text { Railtrack/Network Rail } \\
\text { Network Rail }\end{array}$ & 18,415 & 19,760 & 22,319 & 23,847 & 25,049 & 27,282 & 30,358 & \\
\hline $\begin{array}{l}\text { Interest payments } \\
\text { BR } \\
\text { Railtrack } \\
\text { Railtrack/Network Rail } \\
\text { Network Rail }\end{array}$ & 822 & 886 & 904 & 911 & 936 & 970 & 1,038 & $\begin{array}{l}\text { Totals }(£ \mathrm{~m}) \\
121 \\
1,082 \\
361 \\
8,069\end{array}$ \\
\hline $\begin{array}{l}\text { Dividends } \\
\text { BR } \\
\text { Railtrack } \\
\text { Network Rail }\end{array}$ & & & & & & & & 709 \\
\hline Total dividends and interest & 822 & 886 & 904 & 911 & 936 & 970 & 1,038 & 10,342 \\
\hline
\end{tabular}

Sources: Audited Annual Report and Accounts of British Rail, Railtrack and Network Rail. Nominal values, unadjusted for inflation. 


\section{Table 6}

Additional costs incurred by Network Rail in 2012/2013 arising from its private sector status

Additional costs

Amount Sources

$£ \mathrm{~m}$

1. Outsourcing of renewals and enhancement 250

Network Rail (2013) expenditure

2. Private sector borrowing rates

Network Rail (2013)

Debt Management

Office (2013)

3. Government charge for borrowing guarantee

Total additional costs

$\frac{200}{1,142}$

ORR (2008)

Notes: 1. Actual profit margin is confidential, so assumes 5\% profit margin on $£ 5$ billion of capital expenditure for 2012/13.

2. Interest expense for $2012 / 13$ was $£ 1,415 \mathrm{~m}$ charged on average debt for year of $£ 28,820 \mathrm{~m}$, representing average rate of $4.9 \%$. Government was able to issue 10-year gilts at interest rates of $2.5 \%$ or lower in 2012/13. Rate used here is $2.5 \%$, so additional interest $=2.4 \%$.

3. Planned charge of $£ 1$ billion spread over 5 years (ORR, 2008, p. 15).

Sources: Audited Annual Report and Accounts of Network Rail , 2013. Debt Management Office, 2013, Gilt market. ORR, 2008, Periodic review 2008. 
Table 7

Public performance measure by sector: percentage of trains arriving on time $1997 / 98$ to $2012 / 2013$

\begin{tabular}{llllc}
\hline Year & $\begin{array}{l}\text { Long distance } \\
\text { operators } \\
\%\end{array}$ & $\begin{array}{l}\text { London and SE } \\
\text { operators }\end{array}$ & $\begin{array}{l}\text { Regional } \\
\text { operators }\end{array}$ & $\begin{array}{c}\text { All } \\
\text { operators } \\
\%\end{array}$ \\
& & & & \\
$1997 / 98$ & 81.7 & 89.5 & 90.8 & 89.8 \\
$1998 / 99$ & 80.6 & 87.9 & 88.6 & 87.9 \\
$1999 / 00$ & 83.7 & 87.1 & 89.1 & 87.8 \\
$2000 / 01$ & 69.1 & 77.6 & 81.7 & 79.1 \\
$2001 / 02$ & 70.2 & 77.8 & 79.1 & 78.0 \\
$2002 / 03$ & 76.6 & 78.9 & 80.5 & 79.2 \\
$2003 / 04$ & 73.4 & 80.3 & 82.9 & 81.2 \\
$2004 / 05$ & 79.2 & 84.7 & 82.6 & 83.6 \\
$2005 / 06$ & 82.2 & 87.9 & 85.0 & 86.4 \\
$2006 / 07$ & 84.9 & 88.8 & 87.6 & 88.1 \\
$2007 / 08$ & 86.2 & 90.6 & 89.6 & 89.9 \\
$2008 / 09$ & 87.3 & 91.0 & 90.6 & 90.6 \\
$2009 / 10$ & 88.8 & 91.4 & 92.0 & 91.4 \\
$2010 / 11$ & 87.8 & 91.0 & 91.1 & 90.8 \\
$2011 / 12$ & 89.2 & 91.7 & 92.0 & 91.6 \\
$2012 / 13$ & 87.1 & 91.0 & 91.6 & 90.9 \\
& & & & \\
\hline
\end{tabular}

Note: Arriving "on time" is measured as arriving within 5 min of the published timetable for London and the South East (SE) and regional operators and arriving within $10 \mathrm{~min}$ of the published timetable for the long distance operators

Source: ORR Public Performance Measure by sector, 2013c. 


\section{Appendix A. List and meaning of abbreviations}

1. Rail organisations after privatisation

ORR

ROSCOs

TOCs

2. Consulting firms

DHS

PHB

PMM

TM
The Office of the Rail Regulator (later, The Office of Rail Regulation)

Rolling Stock Companies

Train Operating Companies

3. Public sector organisations and neoliberal-based policy

MISC 94

NAO

NPM

$\underline{4 . \text { Archive source }}$

TNA
Ministerial Committee which reviewed Serpell Report

National Audit Office

New Public Management
Deloitte, Haskins \& Sells, accountants

Putnam, Hayes \& Bartlett

Peat, Marwick, Mitchell, accountants

R. Travers Morgan, engineers

The National Archive 


\section{References}

Adley, R. (1992). Railway privatization. Public Money \& Management, 12(2), 6-7.

Adley, R. (1993) House of Commons debates for 3 February 1993. Hansard, Vol. 36, col. 448. <http://www.parliament.uk/Hansard>. Accessed 10.11.13.

Arnold, P.J., Cooper, C. (1999). A tale of two classes: The privatisation of the Medway ports. Critical Perspectives on Accounting, 10(2), 127-152.

Berglund, J., Werr, A. (2000). The invincible character of management consulting rhetoric: How one blends the incommensurates while keeping them apart. Organization, 7(4), 633-655.

Boxenbaum, E., Rouleau, L. (2011). New knowledge products as bricolage: Metaphors and scripts in organizational theory. Academy of Management Review, 36(2), 272-296.

Bradshaw, W.P. (1991). Comments on the Putnam, Hayes \& Bartlett Paper. The National Archive: AN 192/1040.

Briers, M., Chua, W.F. (2001).The role of actor-networks and boundary objects in management accounting change: A field study of an implementation of activity-based costing. Accounting, Organizations and Society 26(3), 237-269.

British Rail (1983/84 -1993/94). Annual report and accounts. London: BR.

British Railways Board (1989a). Privatisation studies group: Study of structural options for railway privatisation, Vol. 2, prepared by Deloitte, Haskins and Sells on behalf of Department of Transport. The National Archive: AN175/18.

British Railways Board (1989b). Privatisation studies group: Study of structural options for railway privatisation, Vol. 3, prepared by Deloitte, Haskins and Sells on behalf of Department of Transport. The National Archive: AN175/19. 
British Railways Board (1989c). Privatisation studies group: Study of structural options for railway privatisation, Vol. 4, prepared by Deloitte, Haskins and Sells on behalf of Department of Transport. The National Archive: AN175/20.

British Railways Board (1991). Privatisation files. Operating a divided railway, Correspondence: Letter from Bob Reid, BR's Chairman, to Transport Secretary Malcolm Rifkind, 19 April 1991. The National Archive: AN192/1075.

British Railways Board (1992a). Briefing pack for Chairman on white paper: Dinner with Secretary of State, 24 June 1992. The National Archive: AN 192/1070/2.

British Railways Board (1992b). Privatisation files. Building a commercial organization for Railtrack - Appendices to Board recommendations: A report by McKinsey and Company, 1992. The National Archive: AN192/1072.

Callon, M. (1998). The embeddedness of economic markets in economics. In M. Callon (Ed.), The laws of the markets (pp. 1-57). Oxford: Oxford University Press.

Catchpowle, L. Cooper, C., \& Wright, A. (2004). Capitalism, states and accounting. Critical Perspectives on Accounting, 15(8),1037-1058.

Chabrak, N. (2012). Money talks: the language of the Rochester School. Accounting, Auditing \& Accountability Journal, 25(3), 452-485.

Chick M. (1987). Privatisation: The triumph of past practice over current requirements. Business History, 29(4), 104-116.

Christensen, M. (2005). The 'third hand': Private sector consultants in public sector accounting change. European Accounting Review, 14(3), 447-474.

Christensen, M., \& Skaerbaek, P. (2010). Consultancy outputs and the purification of accounting technologies. Accounting, Organizations and Society, 35(5), 524-545. 
Chua, W.F. (1995). Experts, networks and inscriptions in the fabrication of accounting images: a story of the representation of three public hospitals. Accounting, Organizations and Society, 20 (2-3), 111-145.

Clinton-Davis, S. (1995). House of Lords debates for 24 October 1995. Hansard, Vol. 566, cols. 959-961. <http://www.parliament.uk/Hansard>. Accessed 22.12.14.

Cole B., \& Cooper, C. (2006). Deskilling in the $21^{\text {st }}$ century: the case of rail privatisation. Critical Perspectives on Accounting, 17(5), 601-625.

Cooper, D.J., \& Robson, K.. (2006). Accounting, professions and regulation: Locating the sites of professionalization. Accounting, Organizations and Society, 31(5), 415444.

Cullen, Lord (2001). The Ladbroke Grove rail inquiry Part 1 report. Suffolk: HSE Books.

Debt Management Office. (2013). Gilt market 2013. London: DMO. <http://www.dmo.gov.uk>. Accessed 12.11.13.

Dent, J.F. (1991). Accounting and organizational cultures: A field study of the emergence of a new organizational reality. Accounting, Organizations and Society, 16(8), 705732.

Department of Transport. (1983a) Committee on the review of railway finances working papers: Establishment of Serpell Committee by Transport Secretary David Howell, 5 May 1982. The National Archive: MT 131/13.

Department of Transport. (1983b). Committee on the review of railway finances working papers: Letter from P. Sellers, Director of Finance and Planning, British Railways Board, to C. Hayward, Peat, Marwick, Mitchell, 19 October 1982. The National Archive: MT 131/33. 
Department of Transport. (1983c). Committee on the review of railway finances working papers: Report on British Rail by Peat, Marwick, Mitchell, 1982. The National Archive: MT 131/28.

Department of Transport. (1983d). Committee on the review of railway finances working papers: Engineering study of British Railways by Travers, Morgan, 1982. The National Archive: MT 131/35.

Department of Transport. (1991). Track access and charging study: Final report of Putnam, Hayes \& Bartlett. The National Archive: AN 192/1040.

Department of Transport. (1992). New opportunities for the railways - the privatisation of BR (Cmd 2012). London: HMSO.

Department of Transport. (1993). Implementation of privatisation: Overall timetable and control report, 16 July 1993. The National Archive: MT 214/7.

Department of Transport. (1995). Privatisation control group: Action List, 6 October 1995. The National Archive: MT 214/22.

Dudley, G. \& Richardson, J. (2000). Why does policy change? Lessons from British transport policy 1945-99. London: Routledge.

Editorial. (1993). Reading the signals. The Times, 4 November, 20.

Edwards, P. \& Shaoul, J. (2003). Partnerships: for better, for worse? Accounting, Auditing \& Accountability Journal, 16 (3), 397-421.

Fagan, M. (2000). I was right to sell the railway. The Daily Telegraph, 3 December, 8. Flemming, J., \& Mayer, C. (1997). The assessment: public-sector investment. Oxford Review of Economic Policy, 13(4), 1-11. 
Foster, C. (1994). The economics of rail privatisation. London: Chartered Institute of Public Finance and Accountancy.

Funnell, W., Jupe, R., \& Andrew, J. (2009). In government we trust: Market failure and the delusions of privatisation. London: Pluto Press.

Gendron, Y, \& Baker, R. (2005). On interdisciplinary movements: The development of a network of support around Foucaultian perspectives in accounting research. European Accounting Review, 14(3), 525-569.

Gendron, Y., Cooper, D.J., \& Townley, B. (2007). The construction of auditing expertise in measuring government performance. Accounting, Organizations and Society, 32 (1-2), 101-129.

Goodman, J.B., \& Loveman, G.W. (1991). Does privatisation serve the public interest? Harvard Business Review, 69(6), 26-38.

Gourvish, T. (2002). British Rail 1974-97: from integration to privatisation. Oxford: Oxford University Press; 2002.

Grayling, T. (2001). Getting back on track: reforming the ownership and regulation of Britain's railways. London: Institute of Public Policy Research.

Greer, P. (1994). Transforming central government: The next steps initiative. Oxford: Oxford University Press.

Guénin-Paracini, H., Gendron, Y., \& Morales , J. (2014). Neoliberalism, crises and accusations of fraud: a vicious circle of reinforcing influences? Qualitative Research in Accounting \& Management, 11(4), 317-356.

Harris, N.G., \& Godward, E. (1997). The privatisation of British Rail. London: Railway Consultancy Press. 
Harvey, D. A. (2007). A brief history of neoliberalism. Oxford: Oxford University Press. Health and Safety Executive (HSE). (2002). Train derailment at Potters Bar 10 May 2002: Third progress report. London: HSE.

Hood, C. (1995). The "new public management" in the 1980s: variations on a theme. Accounting, Organizations and Society, 20(2/3), 93-109.

Humphrey, C. (1994). Reflecting on attempts to develop a financial management information system for the Probation Service in England and Wales: Some observations on the relationship between the claims of accounting and its practice. Accounting, Organizations and Society, 19(2), 147-178.

Irvine, K. (1987).The right lines. London: The Adam Smith Institute. Irvine, K. (1988). Track to the future. London: The Adam Smith Institute. Jupe, R. (2000). Self-referential lobbying of the Accounting Standards Board: The case of Financial Reporting Standard No. 1. Critical Perspectives on Accounting, 11(3), 337-359.

Jupe, R., \& Crompton, G. (2006). A deficient performance: the regulation of the train operating companies in Britain's privatised railway system. Critical Perspectives on Accounting, 17( 8), 1035-1065.

Jupe, R. (2009a). New Labour, Network Rail and the third way. Accounting, Auditing \& Accountability Journal, 22(5), 709-735.

Jupe, R. (2009b). A "fresh start" or the "worst of all worlds"? A critical financial analysis of the performance and regulation of Network Rail in Britain's privatised railway system. Critical Perspectives on Accounting, 20(2), 175-204. 
Lapsley, I., \& Oldfield, R. (2001).Transforming the public sector: Management consultants as agents of change. European Accounting Review, 10(3), 523-543.

Latour, B., \& Woolgar, S. (1986). Laboratory life: The construction of scientific facts. Princeton, New Jersey: Princeton University Press.

Latour, B. (1987). Science in action. Cambridge, Mass: Harvard University Press.

Latour, B. (1993). We have never been modern. Hemel Hempstead, Herts: Harvester Wheatsheaf;

Latour, B. (1999). On recalling ANT. The Sociological Review, 47(S1), 15-25.

Latour, B. (2005). Reassembling the social - An introduction to Actor-Network Theory. Oxford: Oxford University Press.

Letza, S.R.,Smallman, C., \& Sun, X. (2004). Reframing privatisation: deconstructing the myth of efficiency. Policy Sciences, 37(2), 159-183.

Leys, C. (1999). Intellectual mercenaries and the public interest: Management consultancies and the NHS. Policy and Politics, 27(4), 447-465.

Marsh, R. (1993). House of Lords debates for 2 March 1993. Hansard, Vol. 439, cols. 1142-1143. <http://www.parliament.uk/Hansard>. Accessed 14.11.13.

Martin, B. (1993). In the public interest? Privatisation and public sector reform. London: Zed Books.

McSweeney, B. (2009). The roles of the financial asset market failure denial and the economic crisis: Reflections on accounting and financial theories and practices. Accounting, Organizations and Society, 34(6-7), 835-848.

Milward, R. (1997). The 1940s nationalizations in Britain: Means to an end or the means of production? Economic History Review, 50(2), 209-234. 
Mirowski, P. (2013). Never let a serious crisis go to waste: How neoliberalism survived the financial meltdown. London: Verso.

Morales, J, Gendron, Y., \& Guénin-Paracini, H. (2014). State privatization and the unrelenting expansion of neoliberalism: The case of the Greek financial crisis. Critical Perspectives on Accounting, 25(6): 423-455.

Murray, A. (2001). Off the rails. London: Verso.

Nash, C.A. (2000). Privatization and deregulation in railways: an assessment of the British approach. In W.P. Bradshaw \& H. Lawton Smith (Eds.), Privatization and deregulation of transport (pp. 159-176). London: Macmillan Press.

National Audit Office. (2000). Ensuring that Railtrack maintain and renew the railway network, HC 397. London: The Stationery Office Limited.

National Audit Office. (2001). Purchasing professional services, HC 400. London: The Stationery Office Limited.

National Audit Office. (2006). Central government's use of consultants, HC 128. London: The Stationery Office Limited.

Network Rail. (2003-2013). Annual report and accounts. London: Network Rail.

Niskanen, W.A. (1971). Bureaucracy and representative government. New York: AldineAtherton.

Office of Rail Regulation (ORR). (2008). Periodic review 2008: Determination of Network Rail's outputs and funding for 2009-2014. London: ORR.

Office of Rail Regulation (ORR). (2013a). Opportunities \& challenges for the railway: ORR's long-term regulatory statement. London: ORR. 
Office of Rail Regulation (ORR). (2013b). National rail trends, Government support to the rail industry. London: ORR. 〈http://www.dataportal.orr.gov.uk>. Accessed 14.11.13.

Office of Rail Regulation (ORR). (2013c). Network Rail monitor: Quarter 1 of year 5 of CP4. London: ORR.

Ogden, S.G. Accounting for organizational performance: the construction of the customer in the privatized water industry. Accounting, Organizations and Society, 22(6), 529-556.

Parker, D. (2013). The privatized railways: problems foreseen. Public Money \& Management, 33(5), 313-319.

Pirie. M. (1993). Interview with Madsen Pirie. Economic Affairs, April.

Preston, A.M., Cooper, D.J., \& Coombs, R.W. (1992). Fabricating budgets: A study of the production of management budgeting and the National Health Service. Accounting, Organizations and Society, 17(6), 561-593.

Public Accounts Committee. (2010). Central government's use of consultants and interims, HC 610, session 2010-11. London: The Stationery Office Limited.

Railtrack Group plc. (1995/96-2000/2001). Annual report and accounts. London: Railtrack.

Robson. K. (1991). On the arenas of accounting change: The process of translation. Accounting, Organizations and Society, 16(5-6), 547-570.

Saint-Martin D. (1998). The new managerialism and the policy influences of consultants in government: An historical-institutionalist analysis of Britain, Canada and France. Governance: An International Journal of Policy and Administration, 11(3), 319-356. 
Serpell D. (1983). Railway Finances: Report of a committee chaired by Sir David Serpell. London: HMSO.

Shaoul, J. (1997). A critical financial analysis of the performance of privatised industries: The case of the water industry in England and Wales. Critical Perspectives on Accounting, 8(5), 479-505.

Shaoul, J. (2004). Railpolitik: the financial realities of operating Britain's national railways. Public Money \& Management, 24(1), 27-36.

Shaoul, J. (2005). A critical financial analysis of the Private Finance Initiative; selecting a financing method or allocating economic wealth? Critical Perspectives on Accounting, 16(4), 441-471.

Smith P. (2013). Boom and bust: Top 60 survey. Accountancy, January, 8-14.

Suddaby, R., Cooper, D.J., Greenwood, R. (2007). Transnational regulation of professional services: Governance dynamics of field level organizational change. Accounting, Organizations and Society, 32 (4-5), 333-362.

Terry, F. (2001). The nemesis of privatization: Railway policy in retrospect. Public Money \& Management, 21(1), 4-6.

Topham , G. (2014). Labour's rail shakeup leaves nationalisation off the agenda. The Observer, 3 August, 39.

Toye R. (2004). 'The smallest party in history'? New Labour in historical perspective. Labour History Review, 69(1), 83-103.

Transport Committee. (1983). Serpell Committee Report on the review of railway finances, HC 240, session 1982-83. London: HMSO. 
Transport Committee. (1993). The future of the railways in the light of the Government's White Paper proposals, HC 246-I, session 1992-1993. London: HMSO.

Travis, A., \& Wells, M. (1999). Nationalise Railtrack, says public. The Guardian, 26 October, 1.

Uff, J. (2000). The Southall rail accident report. Suffolk: HSE Books.

Ward, G. (1993). Reforming the public sector: Privatisation and the role of advisers. Political Quarterly, 64(3), 298-305.

Wilson, B. (1994). Consultants and rail privatisation. Early day motion 27 April 1994. Hansard, Vol. 242, motion 1127. <http://www.parliament.uk/Hansard>. Accessed 14.11.13.

Wolmar, C. (1993).All aboard, destination unknown. The Independent, 2 November, 2.

Wolmar, C. (2005). On the wrong line: How ideology and incompetence wrecked Britain's railways. London: Aurum Press; 2005.

Young, J.J. (1995). Defending an accounting jurisdiction: The case of cash flows. Critical Perspectives on Accounting , 6(2), 173-200. 